University of Rhode Island

DigitalCommons@URI

Open Access Master's Theses

1974

\title{
Quinoxaline 1, 4-Dioxides. A Mechanistic Study of Their Formation and the Structural Assignment of 6(7) Isomeric Products
}

Nicholas D. Alteri Jr.

University of Rhode Island

Follow this and additional works at: https://digitalcommons.uri.edu/theses

\section{Recommended Citation}

Alteri, Nicholas D. Jr., "Quinoxaline 1, 4-Dioxides. A Mechanistic Study of Their Formation and the Structural Assignment of 6(7) Isomeric Products" (1974). Open Access Master's Theses. Paper 1119. https://digitalcommons.uri.edu/theses/1119

This Thesis is brought to you for free and open access by DigitalCommons@URI. It has been accepted for inclusion in Open Access Master's Theses by an authorized administrator of DigitalCommons@URI. For more information, please contact digitalcommons-group@uri.edu. 


\section{QUINOXALINE 1,4-DIOXIDES. A MECHANISTIC STUDY OF THEIR FORMATION AND THE STRUCTURAL ASSIGNMENT OF 6(7) ISOMERIC PRODUCTS}

BY NICHOLAS D. ALTERI, JR.

A DISSERTATION SUBMITTED IN PARTIAL FULFILLMENT OF THE REQUIREMENTS FOR THE DEGREE OF MASTER OF SCIENCE IN MEDICINAL CHEMISTRY UNIVERSITY OF RHODE ISLAND 1974 
MASTER OF SCIENCE THESIS

$\mathrm{OF}$

NICHOLAS D. ALTERI, JR.

Approved:

Thesis Committee:

Major Professor
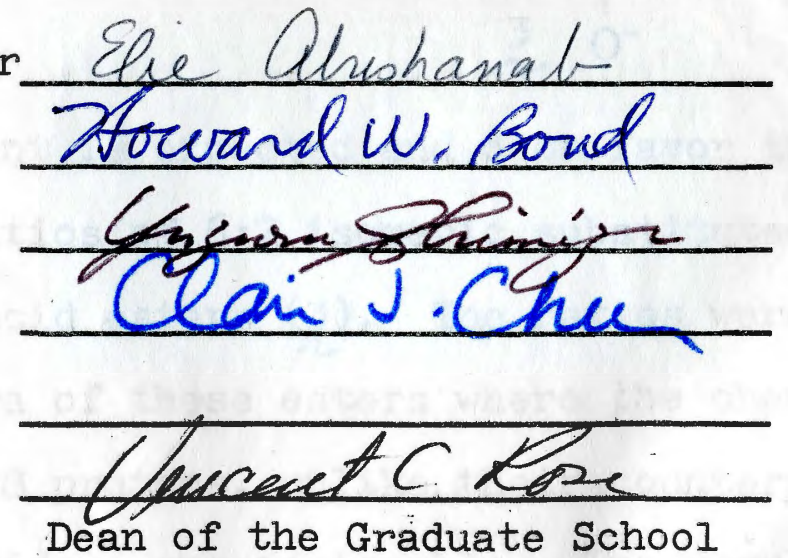

UNIVERSITY OF RHODE ISLAND

1974 


\section{ABSTRACT}

Two types of reactions were used to study the effect of substituents $\left(\mathrm{CH}_{3}, \mathrm{OCH}_{3}\right)$ on the condensation of 5(6)-substituted benzofurazan 1-oxides (1) with (methylthio)-2-propanone (BFO Reaction, A), and 4-substituted o-quinone dioximes (2) with pyruvaldehyde (OQD Reaction, B). The nitrogen atom is an electrophile in reaction $A$ and nucleophile in reaction $B$.

$A$<smiles>[R]c1ccc2no[n+]([O-])c2c1</smiles>

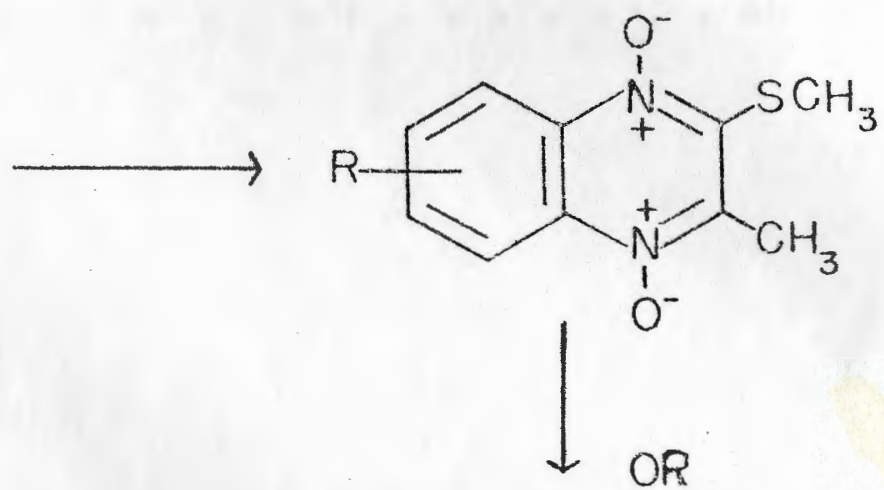

B<smiles>[R]C1=C/C(=N/O)C(=NO)C=CC1</smiles>

2
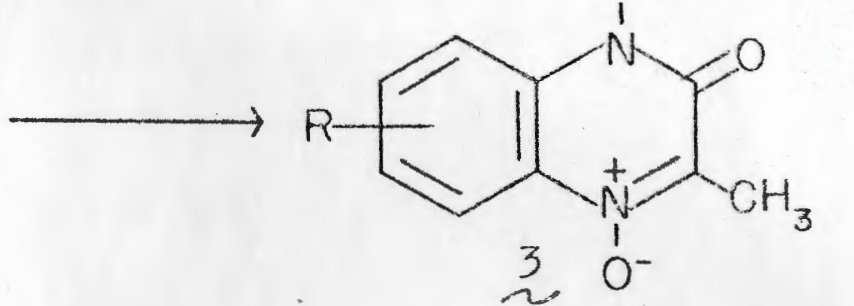

Thus, the same substituent is expected and does favor the formation of opposite ratios of $6: 7$ isomeric substituted quinoxaline hydroxamic acid esters (3). The ratios were determined from nmr spectra of these esters where the chemical shifts of the H-5 and H-8 protons, unlike their counterparts in quinoxaline 1,4- dioxides, are assignable. The results are interpreted by assuming that benzofurazan 1-oxides react in their o-dinitroso tautomeric forms. 


\section{TABLE OF CONTENTS}

I ABSTRACT. . . . . . . . . . . . . i

II LIST OF TABLES AND FIGURES. . . . . . . . . iii

III INTRODUCTION . . . . . . . .....1

IV RESULTS AND DISCUSSION. • • • • • . . 17

$\mathrm{V}$ CONCLUSION. . . . . . . . . . . 31

VI REFERENCES. ............... 40 


\section{LIST OF FIGURES}

Figure 1. Proposed Mechanism for the Condensation of Enamines with BFO. . . . . . . . . 5

Figure 2. Formation of 6- and 7-Substituted Quinoxaline 1,4-Dioxides. . . . . . . . . 7

Figure 3. Stability of 5(6)-Substituted BFO'S. . . . 8

Figure 4. Aromatic Region of the Nmr Spectrum of 6(7)Methoxy-3-Methyl-2-(Methylthio)-Quinoxaline

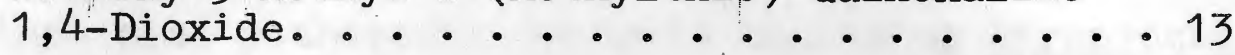

Figure 5. Formation of 6- and 7-Substituted 1-Hydroxy3-Methylquinoxaline 4-Oxides . . . . . 15

Figure 6. The BFO and $\mathrm{OQD}$ Reactions. . . . . . 16

Figure 7. Nmr Spectrum of a Mixture of 6- and 7-Methylhydroxamic Acid Methyl Esters. ..... 24

Figure 8. Nmr Spectrum of a Mixture of 6- and 7-Methoxyhydroxamic Acid Methyl Esters. . . . . . 25

Figure 9. Nmr Spectra of Pure 6- and 7-Methyl Isomers and Their Superimposed Spectrum.

\section{LIST OF TABLES}

Table 1. Chemical Shifts of the 6(7)-Substututed Quinoxaline 1,4-Dioxides ... . . . . 18

Table 2. Chemical Shifts of the Hydroxamic Acid and Imino Compounds. . . . . . . . 20

Table 3. Chemical Shifts of the Hydroxamic Acid Esters. 22

Table 4. Percentage of 7 to 6 Isomers in the Hydroxamic Acid Methyl Esters......... . 23 


\section{INTRODUCTION}

The study of the chemistry and the biological activity of quinoxaline 1,4-dioxides began with the examination of biologically active heterocyclic N-oxides in general. Iodinin ( $\mathcal{L}$, a phenazine 5,10-dioxide which was isolated from Chromobacterium iodinum, was found to have antibacterial activity against some pathogenic bacteria including streptococcus haemolyticus and Corynebacterium diptheriae in concentrations of less than $1 \mu \mathrm{g} / \mathrm{ml} .1,2,3$ Another antibiotic, aspergillic acid (6-sec-butyl-1-hydroxy-3-isobutyl-2(1H)pyrazinone) (2), was isolated from the mold Aspergillus flavus, and was found to have in vitro activity against a number of bacteria.4,5,6 Myxin, 6-methoxy-1-phenazinol 5,10-dioxide (3), an antibiotic originally isolated from a Sporangium mold, 7,8 has been complexed with copper to yield an antomicrobial agent that has a high degree of therapeutic acitivty against gram-positive and gram-negative bacteria, yeasts, etc.9 More recently an antibiotic isolated from Streptomyces ambofaciens was identified as 6-chloroquinoxaline 1,4-dioxide-2-carboxylic acid (4). This compound also has a wide range of antibacterial activity. 10
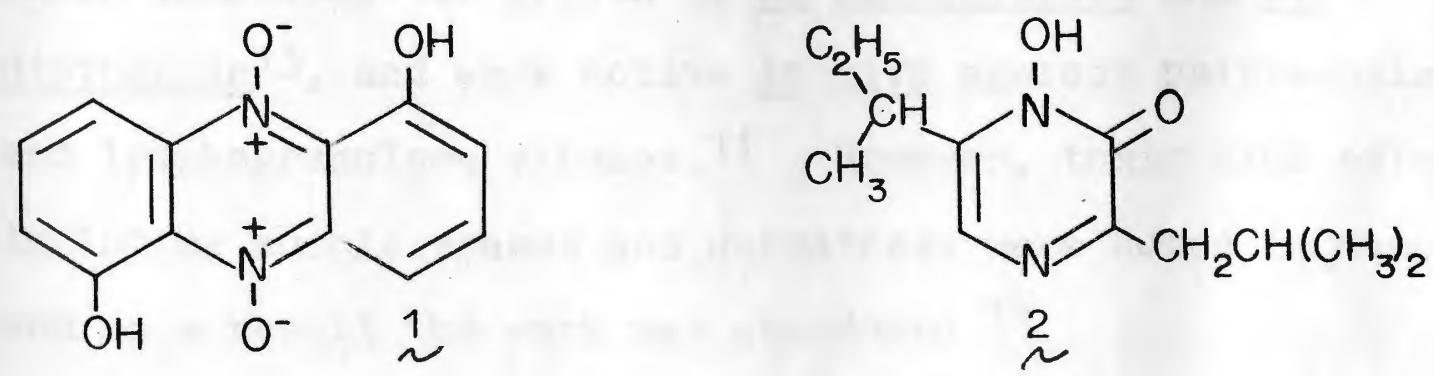


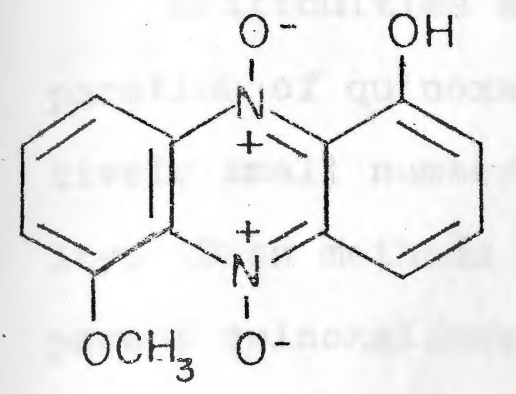

3<smiles>O=C(O)c1c[n+]([O-])c2cc(Cl)ccc2[n+]1[O-]</smiles>

$\stackrel{4}{\sim}$

Historically, quinoxaline 1,4-dioxides were prepared as potential antagonists to vitamin $\mathrm{K}$ (5). However, this antagonism has never been demonstrated, and moreover, their mode of action is now believed to be related to their ability to inhibit DNA synthesis either directly or indirectly.11,12
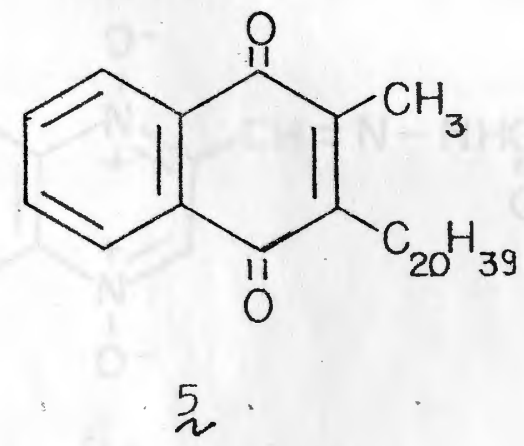

A number of quinoxaline 1,4-dioxides have been synthesized and tested for antibacterial activity. Among these are 2-methyl and 2-amyl-3-methylquinoxaline 1,4-dioxide, Which irhibited the growth of $\mathrm{S}_{0}$ haemolyticus and $\mathrm{C}$. diptheriae $^{13}$, and were active in vivo against psittacosis and Iymphogranuloma viruses. 11 However, toxic side effects including muscle spasms and dermatoses were noted in man, and as a result the work was abandoned. 14 
Difficulties encountered in earlier methods of preparation of quinoxaline 1,4-dioxides account for the relatively small number of analogs tested for biological activity. Such methods involve various peracid oxidations of parent quinoxalines to the corresponding 1,4-dioxides. However, the introduction in 1965 of an elegant one-step synthesis of these compounds, 15,16 rejuvenated the search for suitable candidates resulting in the successful introduction into veterinary medicine of Carbadox, methyl-3-(2-quinoxalinyl methylene) carbazate 1,4-dioxide (6), a growth promoter in swine and poultry, and a highly effective agent in swine dysentery. 17-19

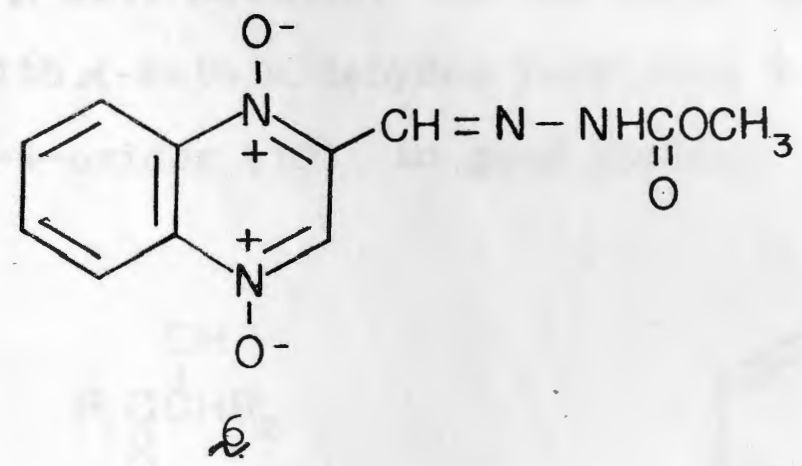

The above synthesis involves the condensation of enamines or enolates with benzofurazan 1-oxides (BFO's), (7), furnishing quinoxaline 1,4-dioxides (8), in yields ranging from 50 to $60 \%$. The general character of this method has allowed the preparation of a large number of quinoxaline 1,4-dioxides ${ }^{20}$ and phenazine 5,10-diaxides ${ }^{21}$. The method is especially useful for the preparation of 2,3- substituted compounds where such substituents inhibit and/or retard the 
peracid oxidation of the parent quinoxaline.

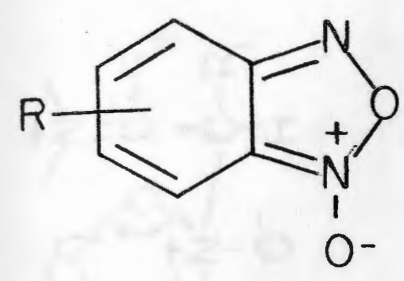

$\lambda$

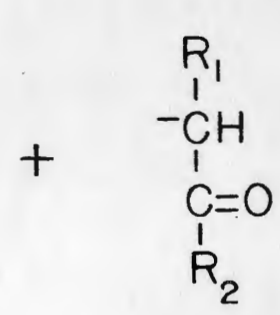

$\mathrm{C}=0$
$\mathrm{R}_{2}$

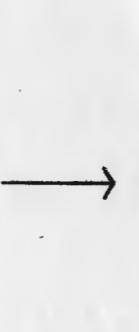

$\rightarrow$<smiles>C[O-]</smiles><smiles>[R]c1ccc2c(c1)[n+](C)c([R])c([R])[n+]2[O-]</smiles>

$\stackrel{8}{\sim}$

Another, but inferior, method for the preparation of quinoxaline 1,4-dioxides was recently reported.22 It involves the condensation of o-quinone dioxime (OQD) (2) with $\alpha$-hydroxy and $\alpha$-keto ketones. On the other hand, condensation of OQD with $\alpha$-keto aldehydes furnishes 1-hydroxyquinoxaline-2-one-4-oxides (10) in good yields.

$\overbrace{\mathrm{NOH}}^{\mathrm{NOH}}$

2

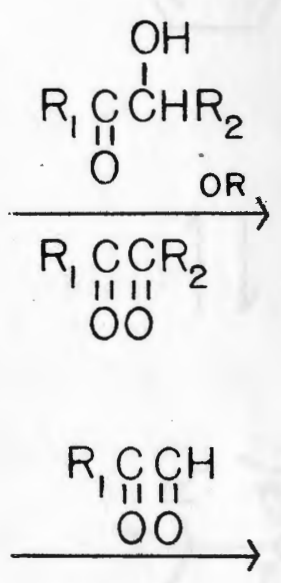

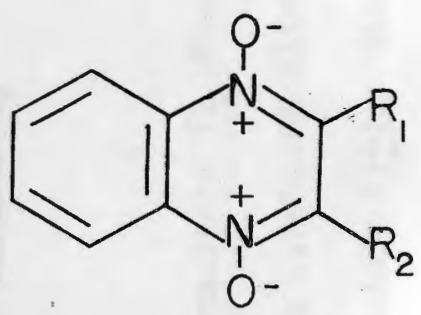

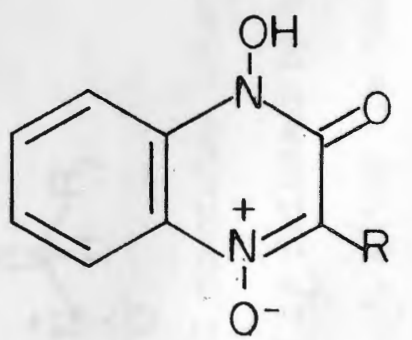

10

The proposed mechanism for the condensation of $\mathrm{BFO}$ with enamines involves initial nucleophilic attack by the carbanion on either N-1 or N-3 (Figure 1). 
Figure 1. Proposed Mechanism for the Condensation of Enamines with BFO<smiles>[R]C(C([R])[N+]1([O-])O[N+]([O-])c2ccccc21)=[N+](C)[O-]</smiles><smiles>[R]C(C)C([R])N([O-])c1ccccc1[N+](=O)[O-]</smiles><smiles></smiles>

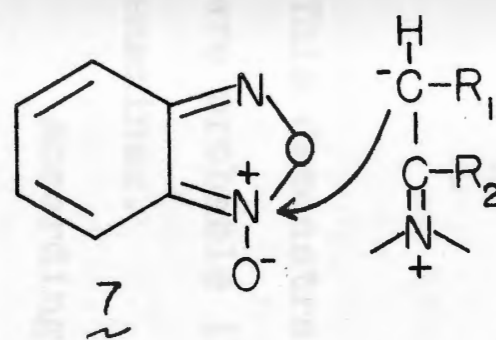<smiles>[R]C1C2C=CC=CC2=[N+]([O-])C([R])([N+](=C)C)C([O-])=[N+]1C</smiles><smiles>[R]c1c([R])[n+]([O-])c2ccccc2[n+]1[O-]</smiles>

12

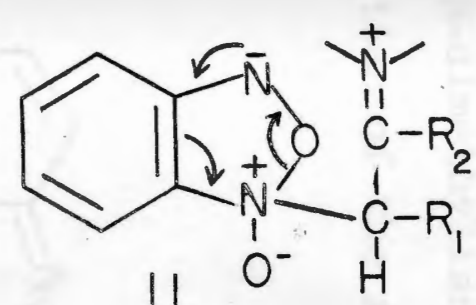
II
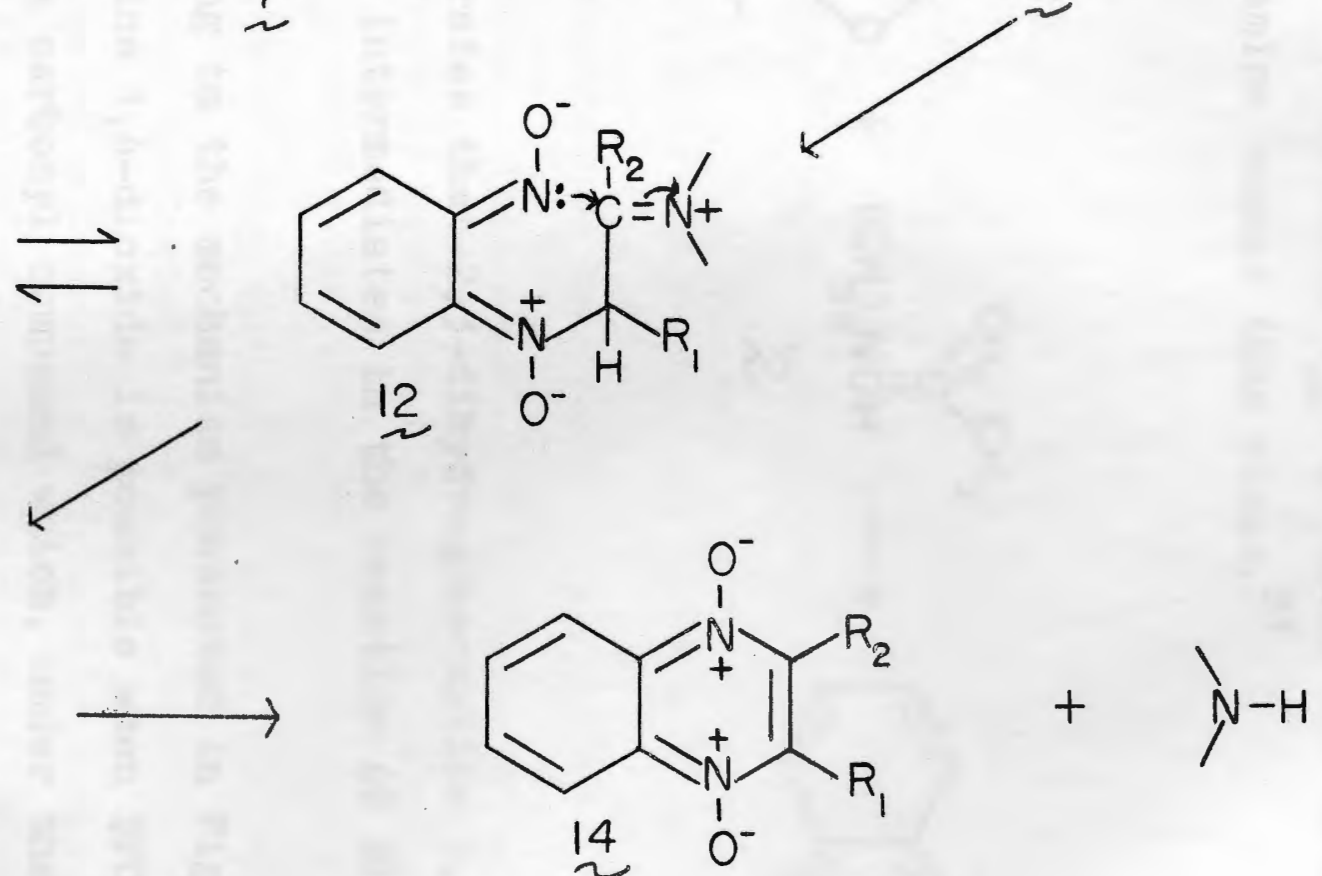

Attack on $\mathrm{N}-1$ furnishes intermediate 11 which undergoes ring opening to form 12 . Cyclization of 12 followed by a 1,2-amine elimination of the resulting dihydroquinoxaline 1,4-dioxide 13, gives the product (14). Similarly, initial attack at $\mathrm{N}-3$ and subsequent ring opening of intermediate 11 a forms $12 a$, which is a tautomer of 12 . 
Support for this mechanism was provided by the isolation and characterization of a 2,3-dihydroquinoxaline 1,4dioxide derivative (16) from the reaction of $\mathrm{BFO}$ with $\mathrm{N}$, $\mathrm{N}$-dimethylisobutenylamine (15) in which the final elimination of the amine cannot take place. 23

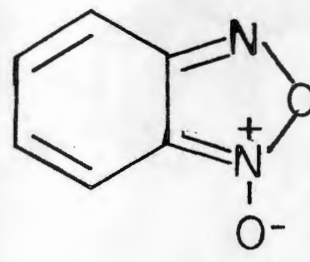

7

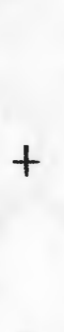

$+\left(\mathrm{CH}_{32}\right)_{2} \stackrel{\mathrm{N}}{\mathrm{C}} \mathrm{H} \longrightarrow$

15

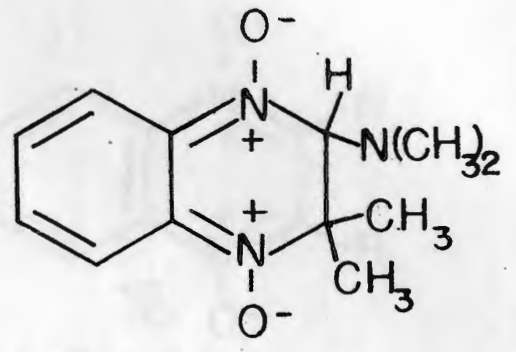

16

This demonstrates that 2,3-dihydroquinoxaline 1,4-dioxides are probable intermediates in the reaction of $\mathrm{BFO}$ and enamines.

According to the mechanism presented in Figure 1 only one quinoxaline 1,4-dioxide is possible when BFO is condensed with a carbonyl compound which, under the reaction conditions, forms one enol. This is not the case, however, in the 5(6)-substituted BFO's, where two isomeric compounds can possibly be formed. These are the 6-and 7-substituted quinoxaline 1,4-dioxides resulting from initial attack at either $\mathrm{N}-1$ or $\mathrm{N}-3$, represented by structures $\underset{\sim}{17}$ and 18 respectively (Figure 2). 

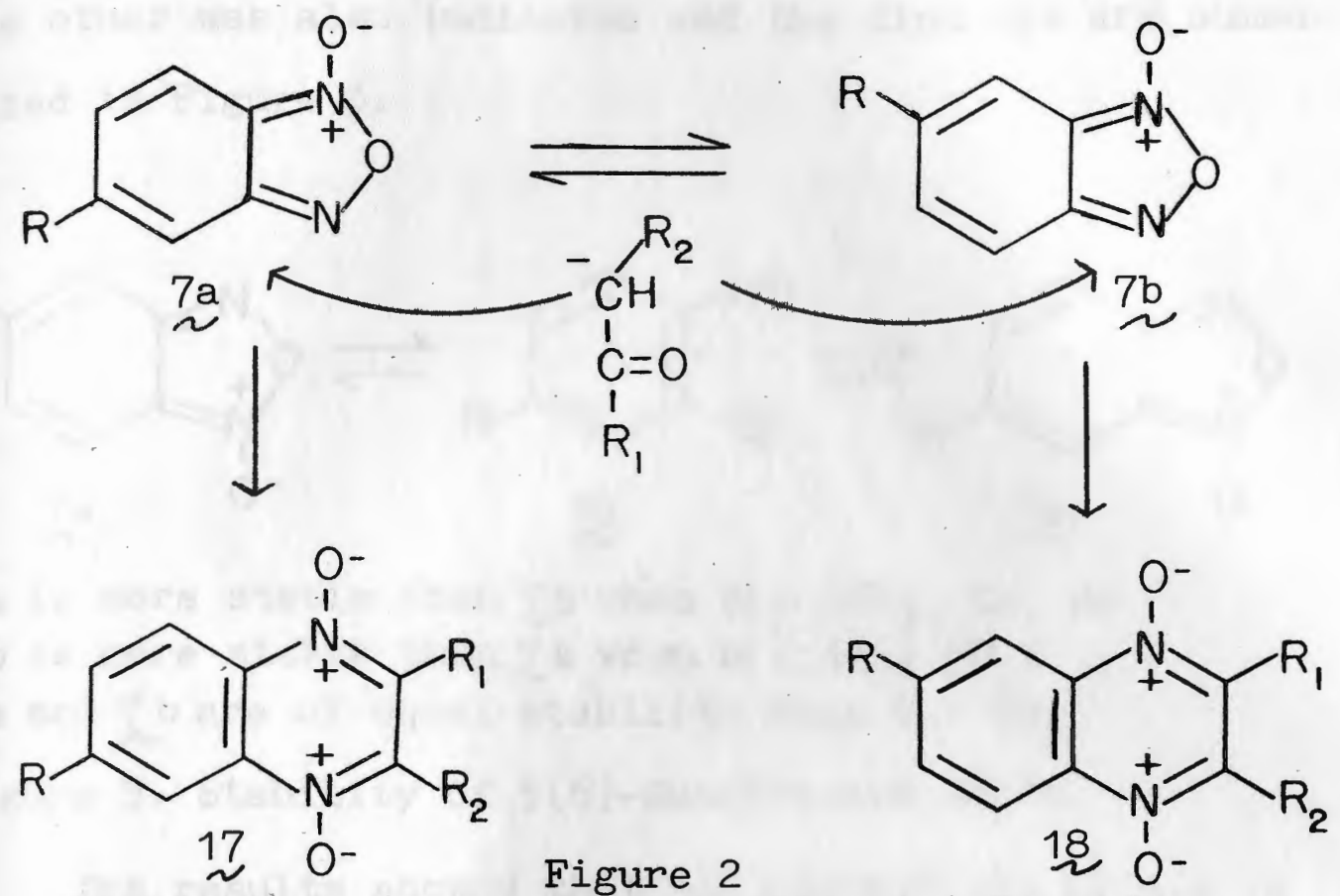

Formation of 6- and 7-Quinoxaline 1,4-Dioxides

A low-temperature $\mathrm{nmr}$ study of BFO helped explain the above prediction. This study established the structure of BFO to be a rapidly equilibrating system between two tautomers $7 \mathrm{a}$ and $7 \mathrm{~b}$ with o-dinitrosobenzene (19) as a plausible intermediate.24-27 The activation energy for the equilibration has been estimated to be about $15 \mathrm{kcal} . / \mathrm{mole} .28$ The tautomerism of a number of 5(6)-substituted BFO's has been studied by low-temperature nmr by Boulton et al. 29 Although a first supposition would be that both electron donor and electron acceptor groups would show a preference for conjugation with the N-oxide group rather than with the other nitrogen atom, this is not the general rule. Boulton's data indicate either that conjugative infiuences of the substituents are small, or that opposing influences are fairly evenly balanced. The stability of one tautomer over 
the other was also indicated and the findings are summarized in Figure 3.

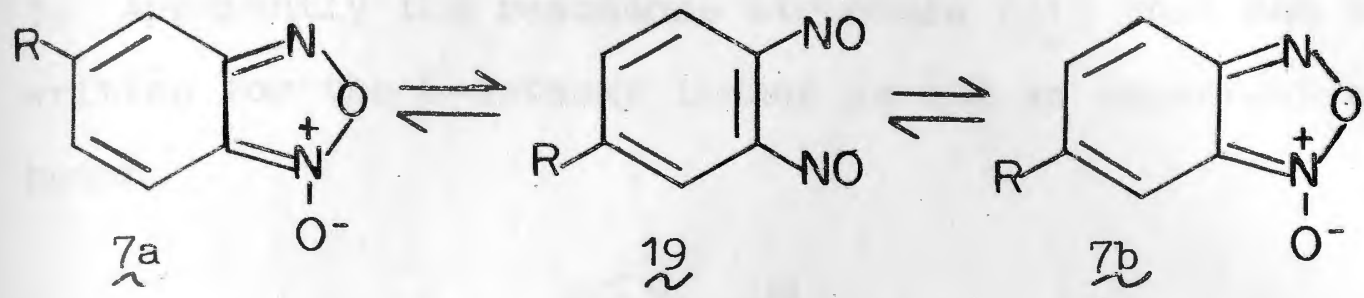

$7 \mathrm{a}$ is more stable than $7 \mathrm{~b}$ when $\mathrm{R}=\mathrm{OCH}_{3}, \mathrm{Cl}, \mathrm{Br}$

$7 \mathrm{~b}$ is more stable than $7 \mathrm{a}$ when $\mathrm{R}=\mathrm{NO}_{2}, \mathrm{CO}_{2} \mathrm{R}$

$7 \mathrm{a}$ and $7 \mathrm{~b}$ are of equal stability when $\mathrm{R}=\mathrm{CH}_{3}$

Figure 3. Stability of 5(6)-Substituted BFO's

The results showed that 5(6)-methyl BFO exists in equal proportions between the 5- and the 6-methyl isomers, which demonstrates that the methyl group has no stabilizing effect on either isomeric form. In contrast, 5(6)-carboxy $\mathrm{BFO}$ exists in a 7 to 3 ratio of the 6-carboxy ( $2 \mathrm{~b}$, $\left.\mathrm{R}=\mathrm{CO}_{2} \mathrm{H}\right)$ to the 5-carboxy $\left(7 \mathrm{a}, \mathrm{R}=\mathrm{CO}_{2} \mathrm{H}\right)$ isomer. In this case the substituent effect can be explained by stabilization through conjugation of the carboxy group in the 6-position with the N-oxide (20).

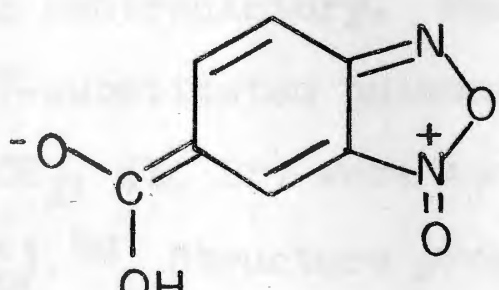


A study of 5(6)-methoxy BFO showed a totally opposite pattern; the 5-methoxy isomer $\left(7 \mathrm{a}, \mathrm{R}=\mathrm{OCH}_{3}\right)$ predominated over the 6-methoxy isomer $\left(7 \mathrm{~b}, \mathrm{R}=\mathrm{OCH}_{3}\right)$ by a ratio of 2 to 1. Apparently the resonance structure $(21)$ that can be written for the 6-methoxy isomer is not an important contributor.

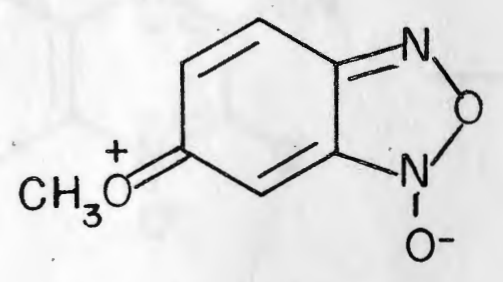

$\stackrel{21}{\sim}$

The authors cite two possible explanations for the preponderance of the 5-methoxy isomer. First, the resonance form may be unfavored because of its accumulation of electron lone pairs in the $\mathrm{N}$-oxide $(\mathrm{N}-1)$ region, and second, dipolar repulsion between the $\mathrm{N}$-oxide and the methoxy group may play an important role in deciding the preferred structure。

Reports on the presence of isomeric products from the reactions of 5(6)-substituted $\mathrm{BFO}^{\prime} \mathrm{s}$ with various nucleophiles have been contradictory. Mason and Tennant isolated only the 7-substituted quinoxaline 1,4-dioxide when BFO's (7, $\left.\mathrm{R}=\mathrm{OCH}_{3}, \mathrm{Cl}, \mathrm{Br}\right)$ were condensed with benzoylacetonitrile (22).30 Structure proof of the products (23) depended upon their conversion to known compounds (24). 


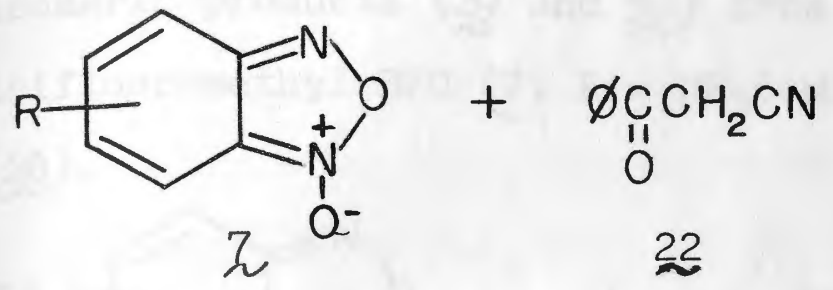<smiles>[R]c1ccc2c(c1)[n+]([O-])c(C#N)c([O-])[n+]2[O-]</smiles>

23

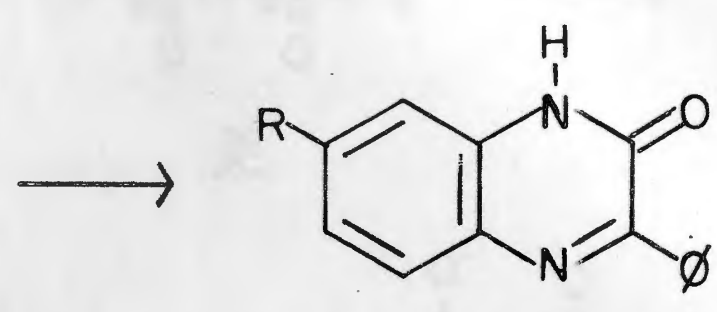

24

On the other hand, Haddadin et al, using wide range melting point criteria, reported the formation of a mixture of isomers (26 and 27) when the 5(6)-substituted BFO's $(7, R=$ $\mathrm{CH}_{3}, \mathrm{OCH}_{3}, \mathrm{Cl}$ ) were condensed with dibenzoylmethane (25). 31
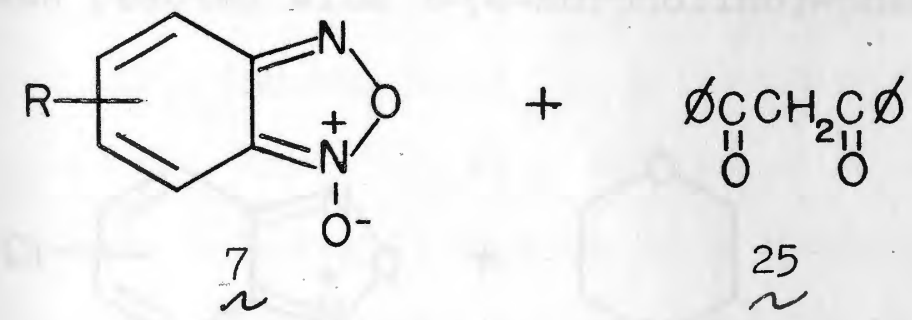

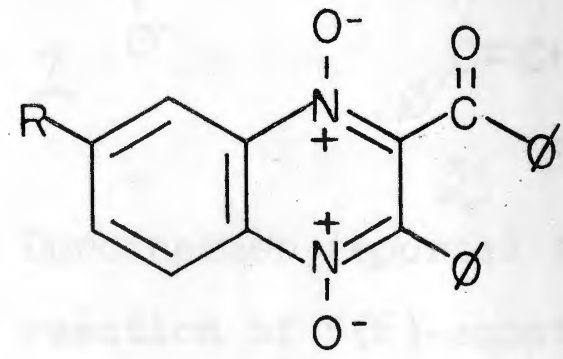

26<smiles></smiles>

27 
Mufarrij et al ${ }^{32}$ likewise reported on the isolation of isomeric products (29 and 30 ) from the reaction of 5(6)trifluoromethyl BFO $\left(7, \mathrm{R}=\mathrm{CF}_{3}\right)$ with 2,4-pentanedione (28).<smiles>[O-][n+]1onc2ccc(C(F)(F)F)cc21</smiles>
7
$+$<smiles>CC(=O)CC(C)=O</smiles>

28

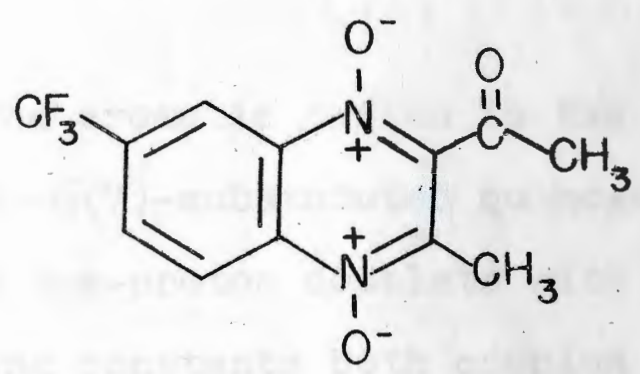

29<smiles>CC(=O)c1c(C)[n+]([O-])c2cc(C(F)(F)F)ccc2[n+]1[O-]</smiles>

30

In the same paper the authors also reported the formation of a single product (32) when $5(6)$-chloro $\mathrm{BFO}(\mathrm{Z}, \mathrm{R}=\mathrm{Cl})$ was reacted with 1-(4-morpholino)-phenylethylene (31).

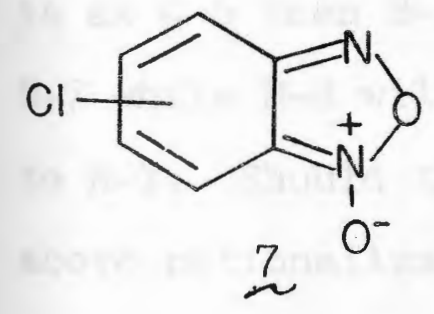

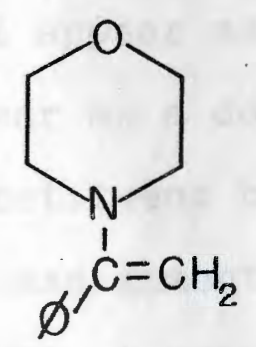

31

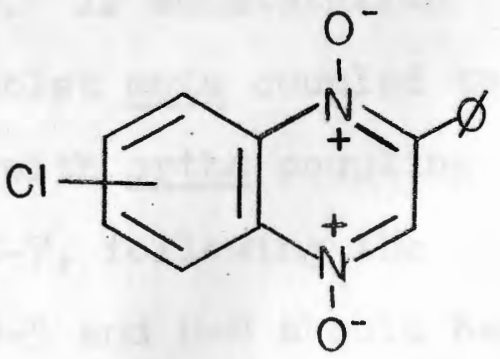

32

Recently Durckheimer reported the formation of isomers from the reaction of 5(6)-substituted BFO's with $\beta$-keto acid esters. 33 While he confirmed the findings of Mason and Tennant on 5-methoxy BFO, he reported the formation of 
6-and 7-chloro quinoxaline 1,4-dioxides when 5-chloro BFO was used.

In the present work a rigorous study of isomer formation was made in which the electronic effects of a 5(6)substituent $\left(\mathrm{R}=\mathrm{OCH}_{3}, \mathrm{CH}_{3}\right)$ on the course of the reaction of BFO with (methylthio)-2-propanone was examined, and the isomer ratios were determined by examining $\mathrm{nmr}$ spectra of suitable derivatives where first order analysis is possible.

The aromatic region in the nmr spectrum of a 2,3dialkyl-6(7)-substututed quinoxaline 1,4-dioxide consists of two one-proton doublets with ortho and meta spin-spin coupling constants both coupled to a third proton appearing as a quartet. The two doublets arise from $\mathrm{H}-5$ and $\mathrm{H}-8$ resonances but chemical shift assignments of these protons is not possible since the position of the substituent at either C-6 or C-7 affects both the chemical shift as well as the coupling constants of these two protons. If substutution is at $\mathrm{C}-6$ then $\mathrm{H}-5$ will appear as a doublet meta coupled to H-7 while $\mathrm{H}-8$ will appear as a doublet with ortho coupling to H-7. Should the substituent be at C-7, following the above rationalization, assignments to $\mathrm{H}-5$ and $\mathrm{H}-8$ should be interchanged and the full structure determination of the compound by $\mathrm{nmr}$ spectral analysis becomes very difficult. (Figure 4) 
<smiles></smiles><smiles>COc1ccc2ccccc2c1</smiles>

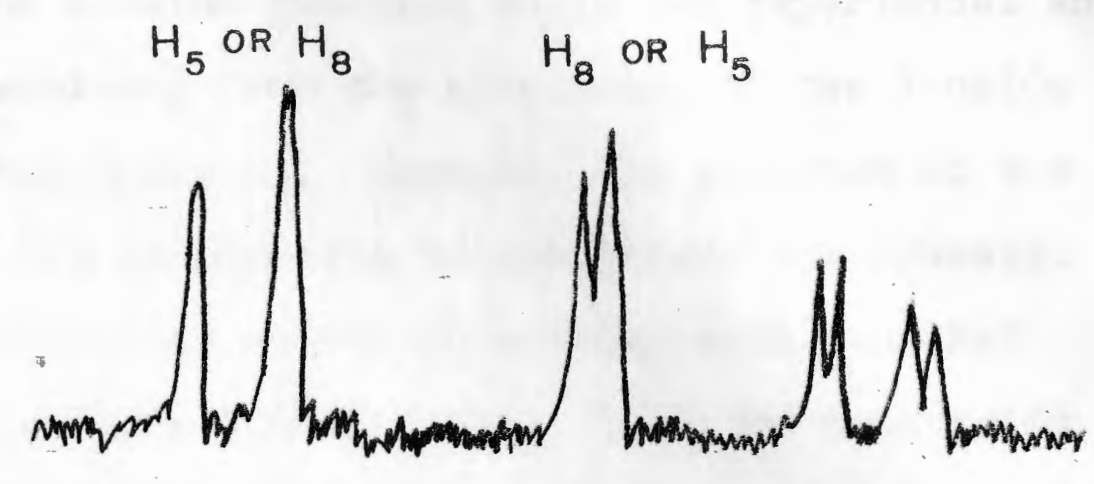

Aromatic Region of the Nmr Spectrum of 6(7)-Methoxy-3-Methyl-2-(Methylthio) Quinoxaline 1,4-Dioxide

Figure 4

Determination of the position of the substituent at either $\mathrm{C}-6$ or $\mathrm{C}-7$ becomes possible by $\mathrm{nmr}$ spectroscopy if a selective modification in the chemical environment of either $\mathrm{H}-5$ or $\mathrm{H}-8$ can be made resulting in predictable chemical shift changes of these protons. Such a modification has been accomplished on 2-cyano-6(7)-methoxy-3-phenylquinoxaline 1,4-dioxide (33) by converting it to 1-hydroxy6(7)-methoxy-3-phenylquinoxaline-2-one-4-oxide (34).30<smiles></smiles>

33

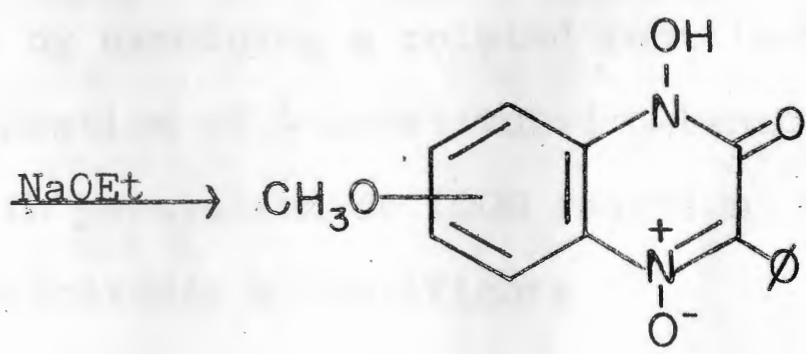

34 
In this product $\mathrm{H}-5$ is still experiencing the deshielding effect of the 4-oxide function while $\mathrm{H}-8$ experiences an upfield shift resulting from the conversion of the 1-oxide group to a hydroxy function. However, the presence of the phenyl group at $\mathrm{C}-3$ is expected to complicate the aromatic region. This problem is solved by working with 3-methyl substituted quinoxaline 1,4-dioxides. Thus, the conversion of 2-methyl-3-(methylthio)-6(7)-substituted quinoxaline:1, 4-dioxides (35) to the corresponding hydroxamic acids (36) provides compounds whose nmr spectra are amenable to first order analysis.

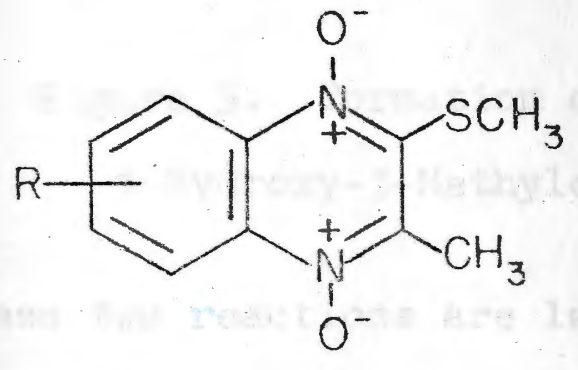

35

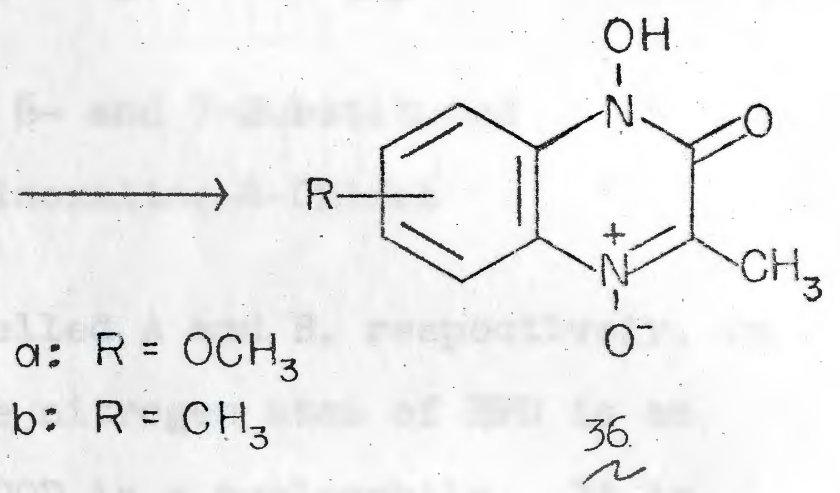

Assessment of the substituent effects on the course of the BFO reaction is made by examining a related reaction ${ }^{22}$ which involves the condensation of 4-substituted o-benzoquinone dioximes (37) with pyruvaldehyde (OQD reaction) to give the corresponding hydroxamic acids (Figure 5). 

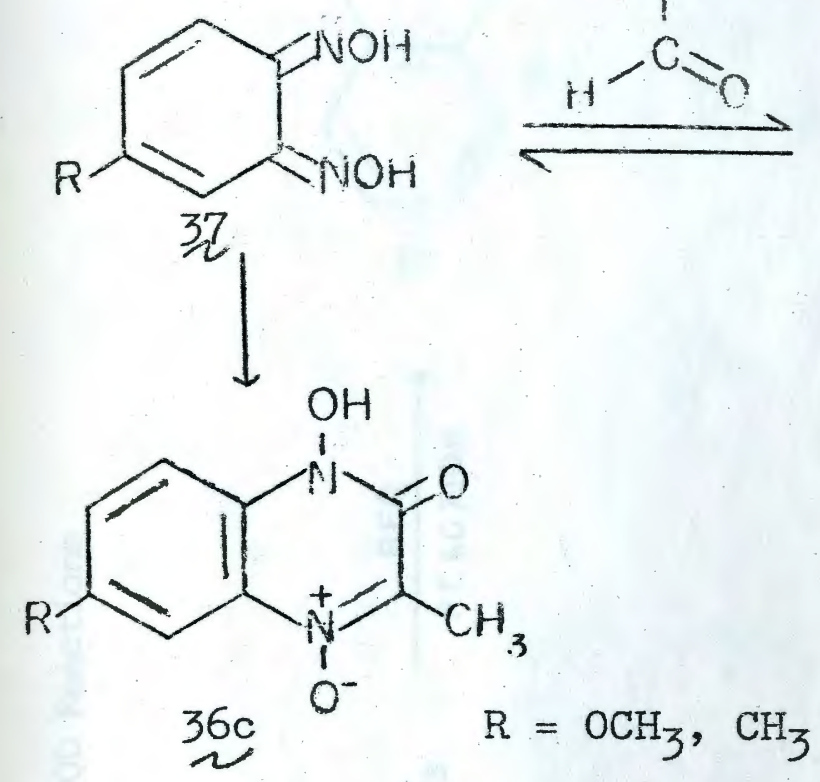
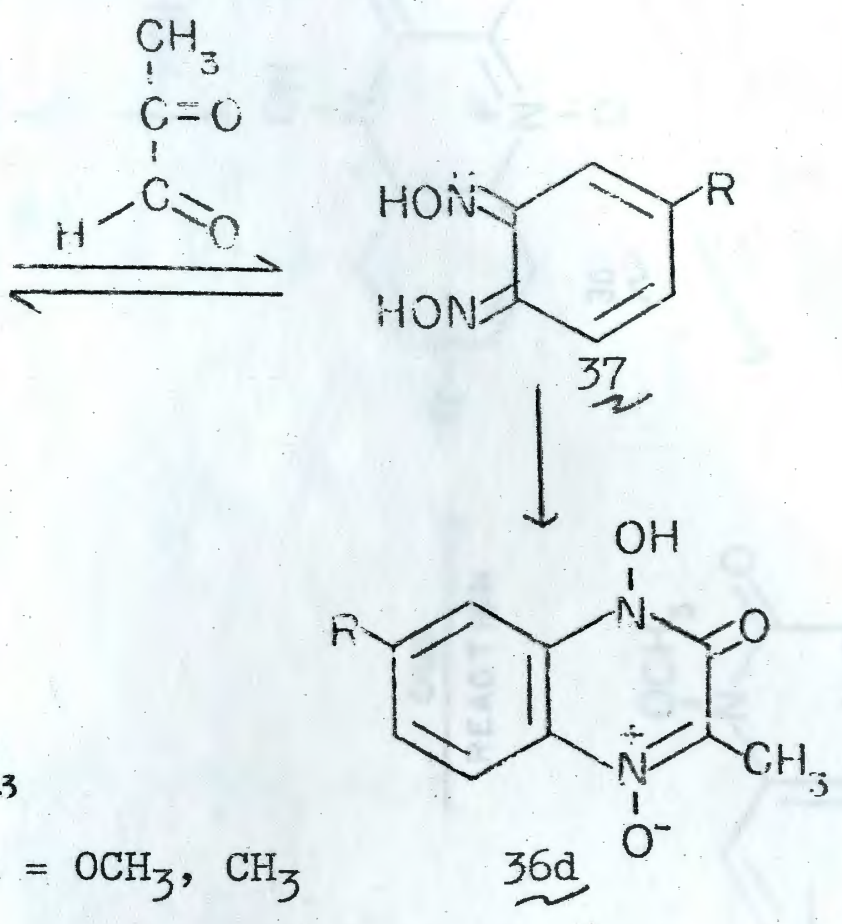

Figure 5. Formation of 6 - and 7-Substituted 1-Hydroxy-3-Methylquinoxaline-4-oxides

These two reactions are labelled $A$ and $B$, respectively, in Figure 6. In reaction A the nitrogen atom of $\mathrm{BFO}$ is an electrophile while that of $O Q D$ is a nucleophile. It is expected that the same substituent would exert opposite effects on the nitrogen atoms involved in these reactions. An electron releasing substituent would reduce the electrophilicity of the nitrogen atom in reaction $\mathrm{A}$ while enhancing its nucleophilicity in reaction $B$. Thus a major isomer in reaction $A$ would be expected to be a minor one in $B$, and vice versa. 
A

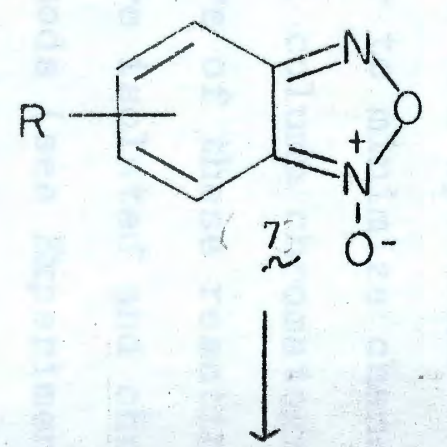

$+\quad \stackrel{0}{\prime \prime} \mathrm{CH}_{3} \stackrel{\mathrm{C}}{\mathrm{CH}_{2} \mathrm{SCH}_{3}}$

$+\mathrm{CH}_{3 \| 11} \mathrm{CH}$<smiles>[R]C1=C/C(=N/O)C(=NO)C=C1</smiles>

37

$a: R=\mathrm{OCH}_{3}$

b: $\mathrm{R}=\mathrm{CH}_{3}$
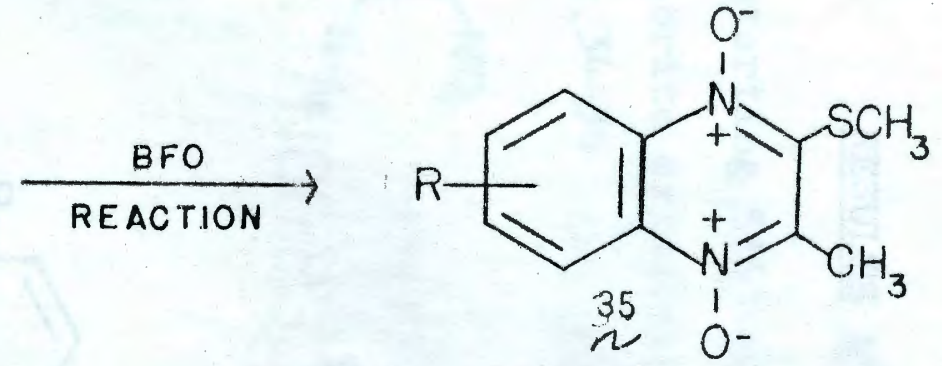

$\downarrow \mathrm{KOH}$
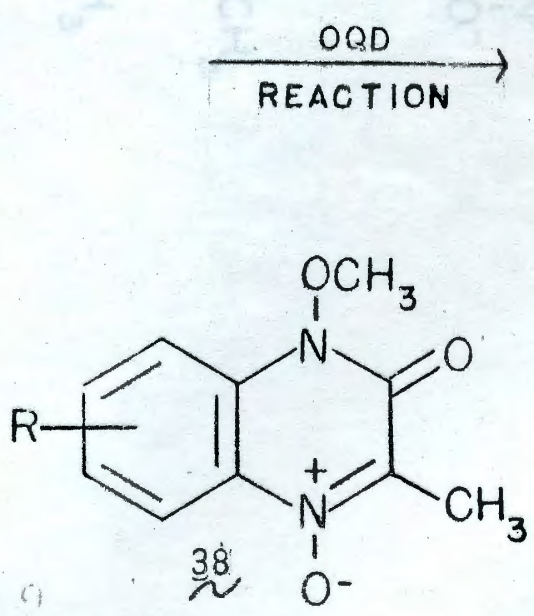


\section{RESULTS AND DISCUSSION}

The starting 5(6)-substituted BFO's (7) were prepared by hypochlorite oxidation of the corresponding o-nitroanilines (39).34-36 The condensation of these BFO's with

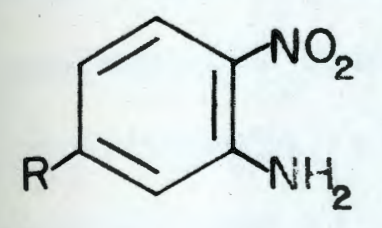

$\stackrel{39}{\sim}$
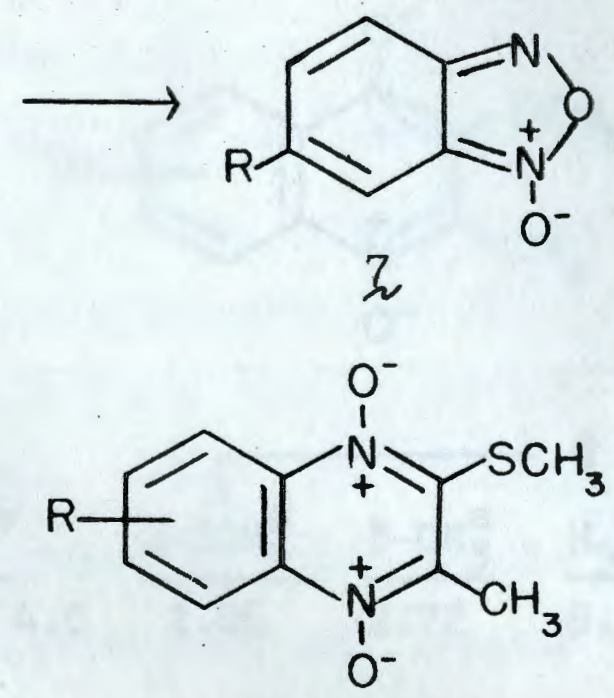

$\stackrel{35}{2}$

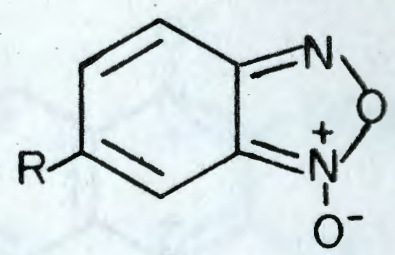

Z

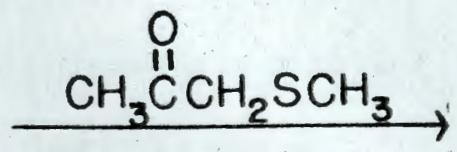

(methylth10)-2-propanone 37 in ammoniacal methanol furnished the desired quinoxaline 1,4-dioxides (35), which crystallized out of the reaction mixture in yields ranging from 50 to $60 \%$. Their ninr spectral data are summarized in Table 1.

In order to minimize chances for the loss of minor isomers, careful column chromatography was conducted on the mother liquors of these reactions. As a result, additional compounds were isolated and characterized by chemical and spectral methods (see Experimental).

Initial elution of the column with benzene gave benzfurazan and the starting BFO. Further elution of the column with more polar solvents gave additional quinoxaline prodicts 


\section{Table 1}

Chemical Shifts of the 6(7)-Substituted Quinoxaline 1,4-Dioxides: *

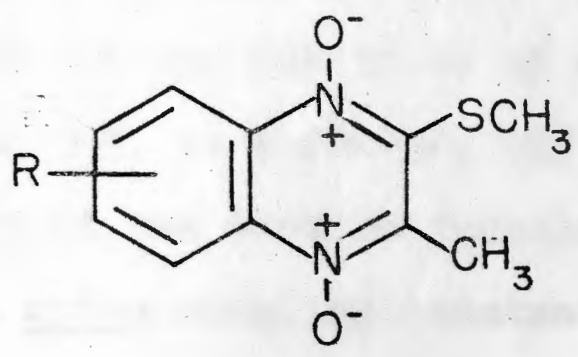

$\begin{array}{lllllll}\frac{\text { comp \# }}{35 \mathrm{a}} & \frac{\mathrm{R}, \delta^{\mathrm{a}}}{\mathrm{OCH}_{3}, 4.0} & \frac{2-\mathrm{SCH}_{3}^{\mathrm{a}}}{2.86} & \frac{3-\mathrm{CH}_{3}^{\mathrm{a}}}{2.72} & \frac{\mathrm{H}_{5}{ }^{\mathrm{b}}}{8.5} & \frac{\mathrm{H}_{6}{ }^{\mathrm{C}}}{7.32} & \frac{\mathrm{H}_{8}{ }^{\mathrm{b}}}{7.86} \\ 35 \mathrm{~b} & \mathrm{CH}_{3}, 2.88 & 2.72 & 2.62 & 8.9 & 7.63 & 8.34\end{array}$

Determined in $\mathrm{CDCl}_{3}$ and expressed in ppm downfield from TMS. The expected multiplets with usual ortho, meta, and para coupling constants were observed. asinglet, bdoublet $(J=9 \mathrm{~Hz}$, or $\mathrm{J}=2 \mathrm{~Hz})$, c quartet $(J=9 \mathrm{~Hz}, J=2 \mathrm{~Hz})$.

*The assignments of $\mathrm{H}_{5}$ and $\mathrm{H}_{8}$ can be interchanged. 
whose elemental analyses and mass spectral data showed the loss of sulfur with the incorporation of an additional nitrogen in their structures. The nmr spectra confirmed this finding as indicated by the disappearance of the $\mathrm{S}_{-} \mathrm{CH}_{3} \mathrm{sig}-$ nal. (See Table 2). Furthermore, the aromatic region of the spectra showed $\mathrm{H}-5$ and $\mathrm{H}-8$ to be in different chemical environments, with $\mathrm{H}-5$, as expected, still experiencing the deshielding effect of the 4-oxide function and appearing as a doublet with an ortho coupling constant, $(\mathrm{J}=9 \mathrm{~Hz})$. On the other hand, $\mathrm{H}-8$ was shifted upfield and was meta coupled to $\mathrm{H}-6(\mathrm{~J}=2 \mathrm{~Hz})$. These data strongly suggest structure (41) for these compounds. The 2-imino tautomeric form (41) seems to be preferred over the 2-amino tautomer (40a) as indicated by its spectral properties. Differences in the chemical shifts of $\mathrm{H}-5$ and $\mathrm{H}-8$ cannot be easily explained by the 2-amino structure.
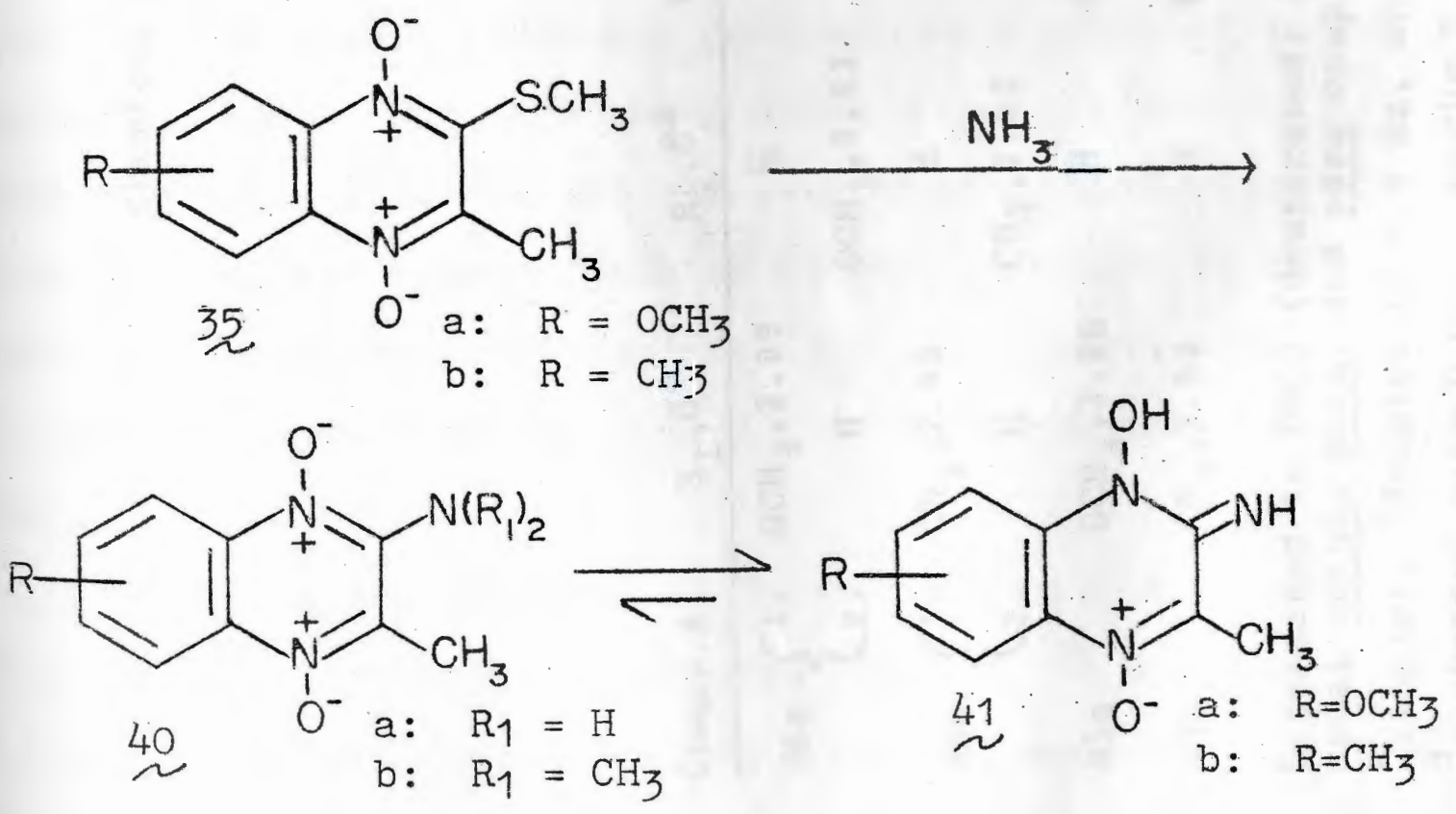


\section{TABLE 2}

Chemical Shifts of Hydroxamic Acid and

Imino Compounds

\begin{tabular}{|c|c|c|c|c|c|c|c|c|c|}
\hline Comp. \# & $\mathrm{R}_{1}, \delta^{\mathrm{a}}$ & $\mathrm{R}_{2}, \delta^{\mathrm{a}}$ & $x, \delta^{a, d}$ & $1-\mathrm{OH}^{\mathrm{a}, \mathrm{d}}$ & $3-\mathrm{CH}_{3}{ }^{\mathrm{a}}$ & $\mathrm{H}_{5}^{\mathrm{b}}$ & $\mathrm{H}_{6}^{\mathrm{c}}$ & $\mathrm{H}_{7}^{\mathrm{C}}$ & $\mathrm{H}_{8}^{\mathrm{b}}$ \\
\hline $36 a\left\{^{1 .}\right.$ & $\mathrm{OCH}_{3}, 3.88$ & $\mathrm{H}$ & 0 & $7.0-7.2$ & 2.38 & 8.15 & 7.13 & -- & 6.93 \\
\hline$\{2$. & $\mathrm{H}$ & $\mathrm{OCH}_{3}, 3.83$ & 0 & $7.0-7.2$ & 2.41 & 7.36 & -- & 7.04 & 7.44 \\
\hline $36 \mathrm{~b}\{1$. & $\mathrm{CH}_{3}, 2.45$ & $\mathrm{H}$ & 0 & $7.0-7.2$ & 2.41 & 7.96 & 7.23 & -- & 7.58 \\
\hline 2. & $\mathrm{H}$ & $\mathrm{CH}_{3}, 2.43$ & 0 & $7.0-7.2$ & 2.43 & 8.06 & -- & 7.65 & 7.65 \\
\hline $41 a$ & $\mathrm{OCH}_{3}, 3.86$ & $\mathrm{H}$ & $\mathrm{N}-\mathrm{H}, 2.9$ & 7.0 & 2.50 & 8.15 & 7.05 & -- & 7.58 \\
\hline $\mathrm{b}$ & $\mathrm{CH}_{3}, 2.57$ & $\mathrm{H}$ & $\mathrm{N}-\mathrm{H}, 3.3$ & 7.5 & 2.54 & 8.31 & 7.49 & -- & 8.17 \\
\hline
\end{tabular}

Determined in DMSO (deuterated) and expressed in Ppm downfield from DSS.* The usual ortho, meta, and para coupling constants were observed.

a singlet, $b_{\text {doublet }}(\mathrm{J}=9 \mathrm{~Hz}$, or $\mathrm{J}=2 \mathrm{~Hz}), \mathrm{C}_{\text {quartet }}(\mathrm{J}=9 \mathrm{~Hz}, \mathrm{~J}=2 \mathrm{~Hz})$ dexchanged with $\mathrm{D}_{2} \mathrm{O}$. *sodium 2,2-dimethyl-2-silapentane sulfate 
Furthermore, the ultraviolet maxima of 2-dimethylamino-3methylquinoxaline 1,4-dioxide $\left(4^{40 b}\right)^{23}$ are not observed in the compounds, suggesting preference for the imino structure.

More than one mechanistic pathway can explain the formation of the imino products. Direct ammonolysis of the methylthio group in the reaction mixture appeared as the most plausible explanation. Indeed, ammonolysis of 7-methoxy-2-methyl-3-(methylthio)-quinoxaline 1,4-dioxide (35a, $\mathrm{R}=\mathrm{OCH}_{3}$ ) and 2,7-dimethyl-3-(methylthio)-quinoxaline 1,4dioxide $\left(35 \mathrm{~b}, \mathrm{R}=\mathrm{CH}_{3}\right)$ under similar conditions to those used in the BFO reaction furnished the corresponding 7-methoxy and 7-methyl-2-imino compounds ( $4_{2} 1 \mathrm{a}$ and $\underbrace{41 b}_{\sim})$, respectively. The above finding suggested that base hydrolysis of 3(methythio)-quinoxaline 1,4-dioxides should proceed to give the corresponding hydroxamic acids. This proved to be the case and the highly insoluble products were obtained in excellent yields. The hydroxamic acids whose nmr spectral data are summarized in Table 2 were quantitatively esterified with either diazomethane or dimethyl sulfate to the chloroform-soluble methyl esters ( 37 ), which were subjected to nmr analysis. The nmr data for those compounds are in Table 3 .

The o-quinone dioximes (37) were prepared by reducing the corresponding 5(6)-substituted BFO's.36,38 Condensation of the oximes with pyruvaldehyde proceeded smoothly in aqueous medium to give the desired hydroxanic acids in very high 


\section{TABLE 3}

Chemical Shifts of the Hydroxamic Acid Esters

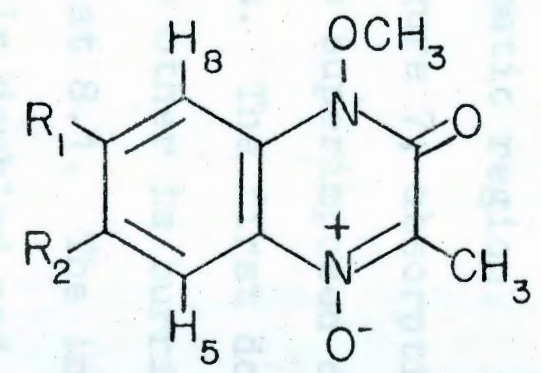

\begin{tabular}{|c|c|c|c|c|c|c|c|c|}
\hline $\mathrm{mp}$. & $\mathrm{R}, \delta^{\mathrm{a}}$ & $R, \delta^{a}$ & $3-\mathrm{CH}_{3}, \delta^{\mathrm{a}}$ & $1-\mathrm{OCH}_{3}, \mathrm{~S}^{\mathrm{a}}$ & $\mathrm{H}_{5} \mathrm{~b}$ & $\mathrm{H}_{6}{ }^{\mathrm{C}}$ & $\mathrm{H}_{7}^{\mathrm{C}}$ & $\mathrm{H}_{8}{ }^{b}$ \\
\hline a & $\mathrm{H}$ & $\mathrm{OCH}_{3}, 3.95$ & 2.57 & 4.18 & 7.9 & -- & 7.31 & 7.61 \\
\hline & $\mathrm{OCH}_{3}, 3.98$ & $\mathrm{H}$ & 2.53 & 4.17 & 8.50 & 6.98 & -- & 6.98 \\
\hline $\mathrm{b}$ & $\mathrm{H}$ & $\mathrm{CH}_{3}, 2.50$ & 2.53 & 4.16 & 8.23 & -- & $7 \cdot 2-7 \cdot 6$ & $7.2-7$ \\
\hline & $\mathrm{CH}, 2.53$ & $\mathrm{H}$ & 2.53 & 4.16 & 8.23 & 7.2 & & 7.4 \\
\hline
\end{tabular}

Determined in $\mathrm{CDCl}_{3}$ and expressed in ppm downfield from TMS. The usual ortho, meta, and para coupling constants were observed.

$a_{\text {singlet, }} b_{\text {doublet }}(\mathrm{J}=9 \mathrm{~Hz}$, or $\mathrm{J}=2 \mathrm{~Hz}), c_{\text {quartet }}(\mathrm{J}=9 \mathrm{~Hz}, \mathrm{~J}=2 \mathrm{~Hz})$. 
yields. Similarly these were esterified and subjected to nmr analysis.

The aromatic regions of the nmr spectra of the hydroxamic acid esters (37a and 37b) obtained from BFO reactions are shown in Figures 7 and 8, respectively. Differences in the chemical shifts of the $\mathrm{H}-5$ nuclei, which are doublets with meta coupling constants $(J=2 \mathrm{~Hz}$ ) in one case and ortho $(J=9 \mathrm{~Hz})$ in the other, allow the detection of the minor isomers. Their percentage is calculated directly from the integration spectrum as compared to the remainder of the aromatic region.

In Figure 7 , absorptions between 8.0 and 8.2 correspond to two superimposed doublets of the $\mathrm{H}-5$ protons in the two isomers. The first doublet, $(J=9 \mathrm{~Hz})$, has one leg at 8.2 and the other is burried under the second $\mathrm{H}-5$ doublet $(J=2 \mathrm{~Hz})$ at 8.1. The integration corresponding to one leg at 8.2 is doubled and subtracted from the total integral. for that region to obtain the ratios of isomers. The percentages of 7:6 isomers are summarized in Table 4. As was predicted earlier, a major isomer in the BFO reaction became the minor one in the OQD reaction.

Table 4. Percentages of 7 to 6 Isomers in the Hydroxamic Acid Methyl Esters

\begin{tabular}{|c|c|c|c|c|c|}
\hline $\mathrm{R}$ & \multicolumn{2}{|c|}{ BFO Reaction (A) } & \multicolumn{3}{|c|}{ OQD Reaction (B) } \\
\hline$-\mathrm{OCH}_{3}$ & 83 & 17 & 20 & : & 80 \\
\hline$-\mathrm{CH}_{3}$ & 71 & 29 & 35 & : & 65 \\
\hline
\end{tabular}




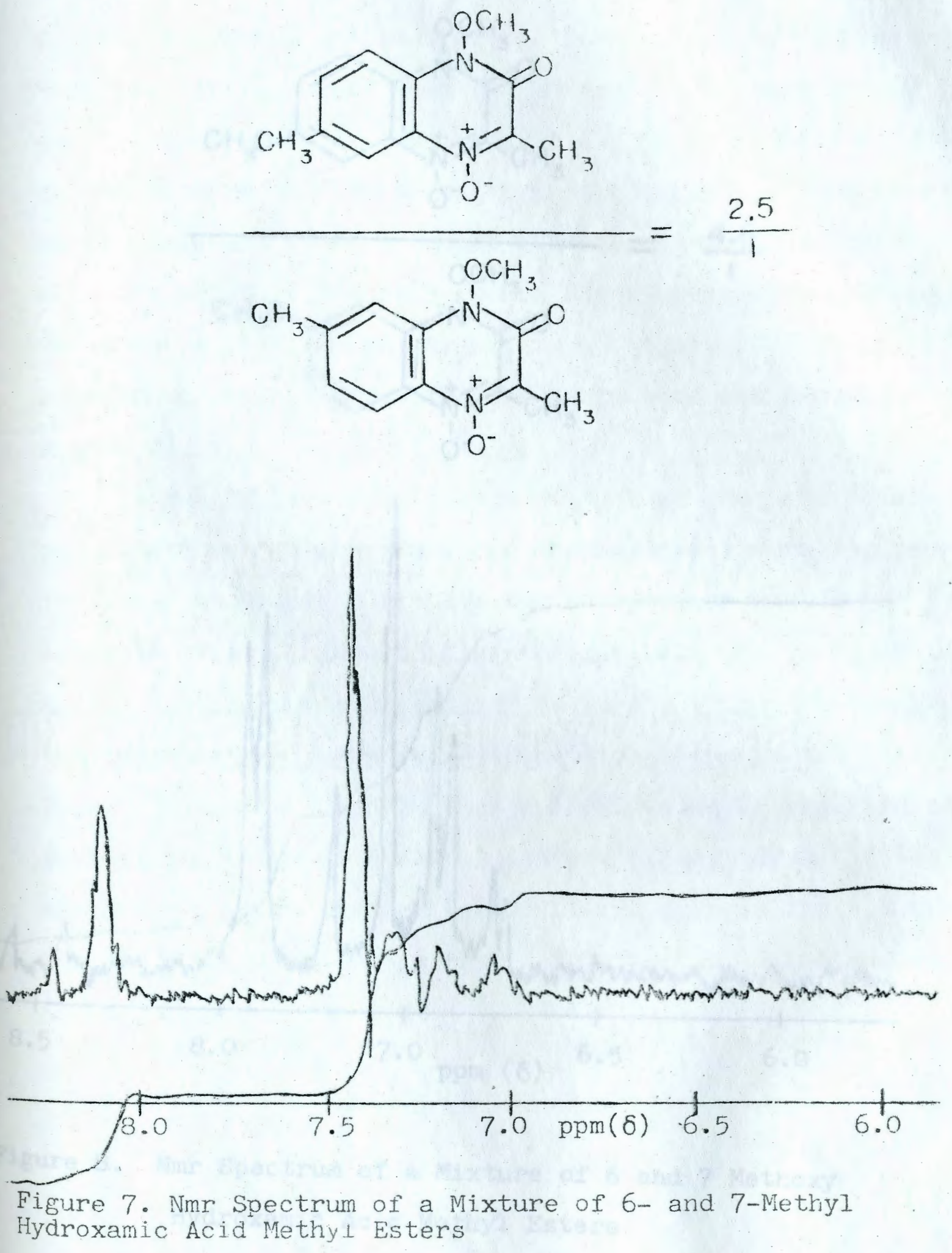



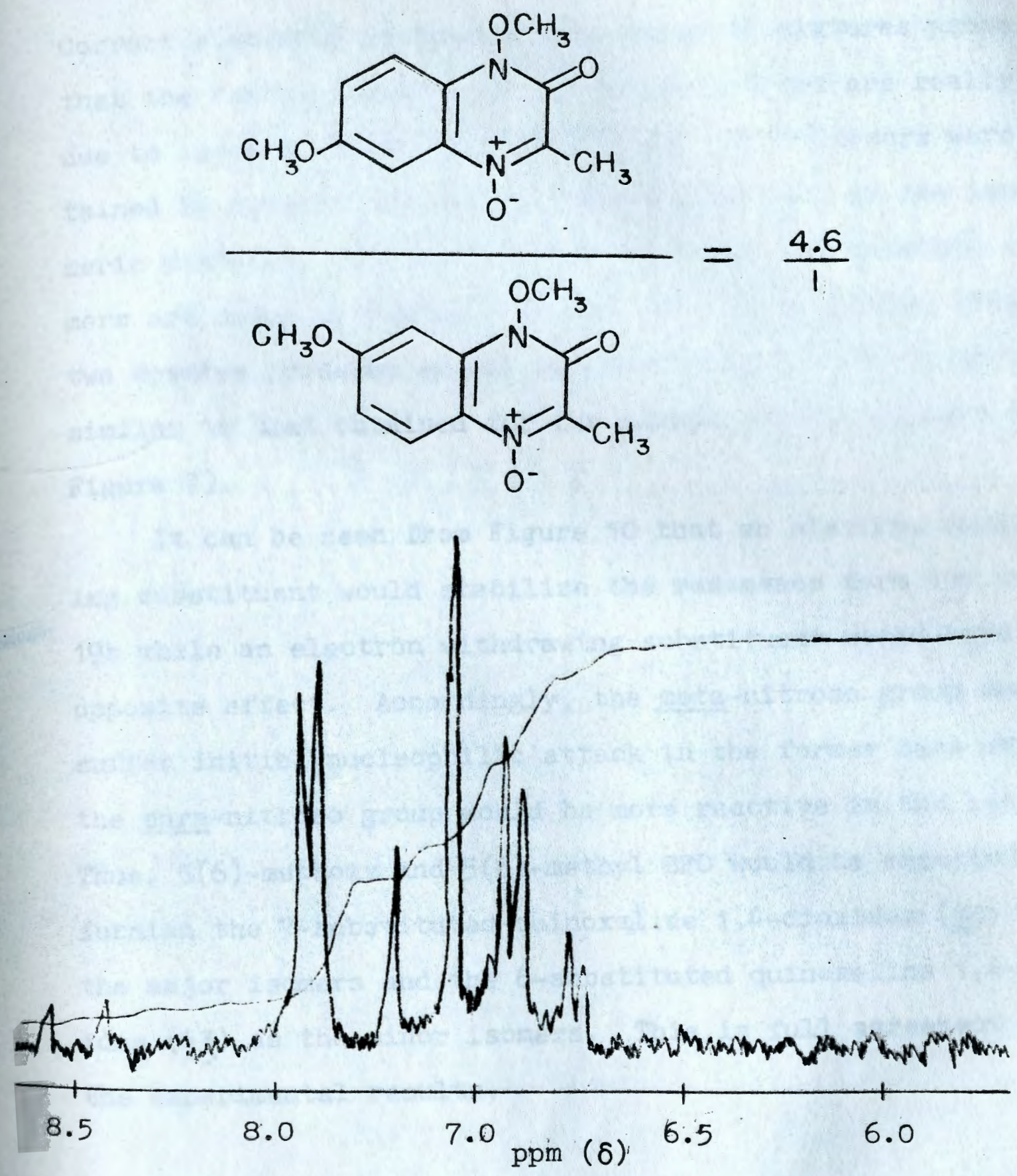

Figure 8. Nmr Spectrum of a Mixture of 6 and 7 Methoxy Hydroxamic Acid Methyl Esters 
Correct elemental analyses of the isomeric mixtures prove that the "extra peaks" seen in the nmr spectra are really due to isomers rather than impurities. Fure isomers were obtained by repeated fractional crystallizations of the isomeric mixtures. The nmr spectra of the 7- and 6-methyl isomers are shown in Figure 9 ( $A$ and $B$ ). Superimposing these two spectra produces an nmr spectrum (Figure 9,C) which is similar to that obtained for the mixture of the isomers (see Figure 7).

It can be seen from Figure 10 that an electron donating substituent would stabilize the resonance form 19a over $19 \mathrm{~b}$ while an electron withdrawing substituent would have the opposite effect. Accordingly, the meta-nitroso group would suffer initial nucleophilic attack in the former case while the para-nitroso group would be more reactive in the latter. Thus, 5(6)-methoxy and 5(6)-methyl BFO would be expected to furnish the 7-substituted quinoxaline 1,4-dioxides (42) as the major isomers and the 6-substituted quinoxaline 1,4-dioxides (43) as the minor isomers. This is full agreement with the experimental results. 


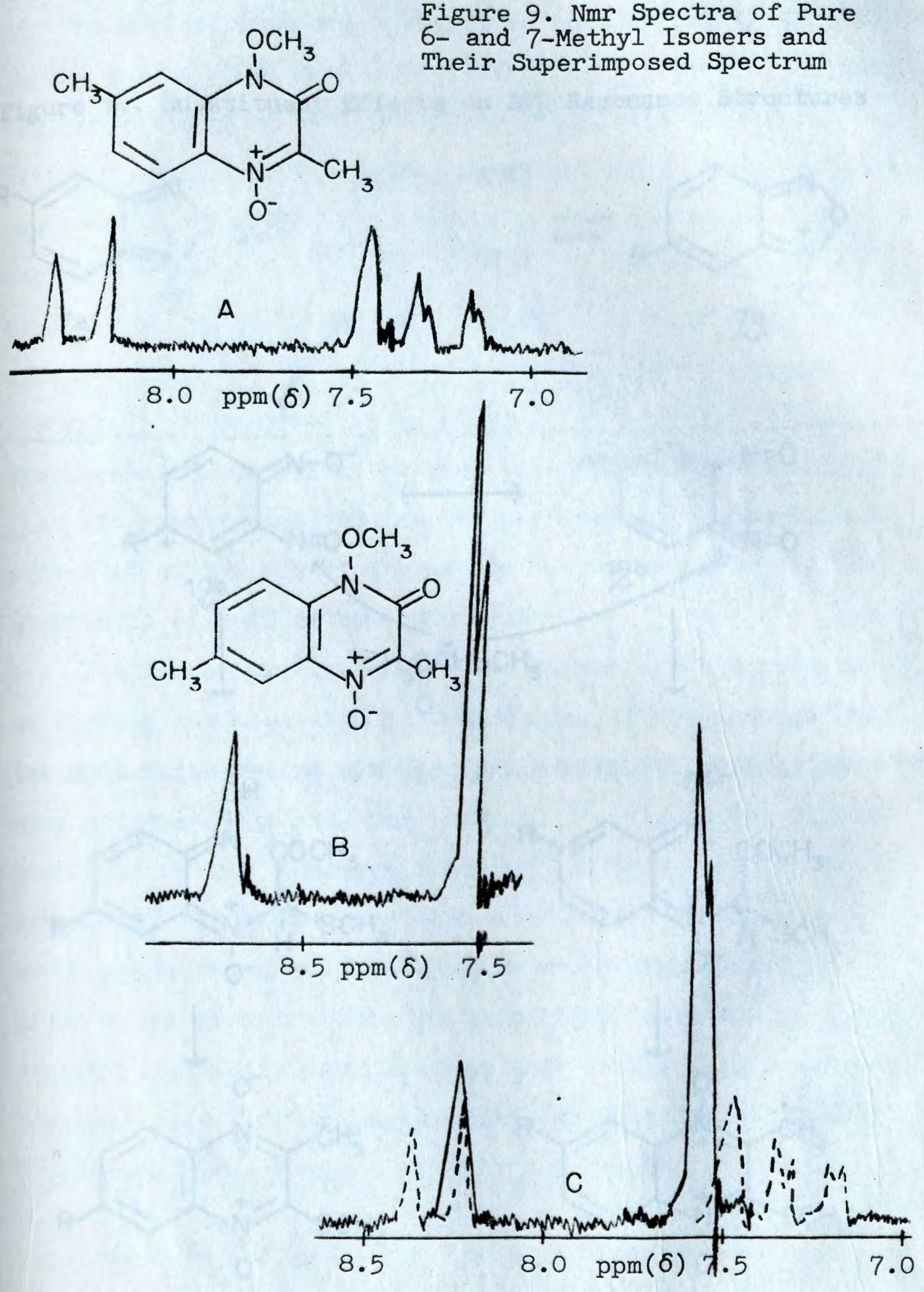


Figure 10. Substituent Effects on BFO Resonance Structures<smiles>[R]c1ccc2c(c1)no[n+]2[O-]</smiles>

7a
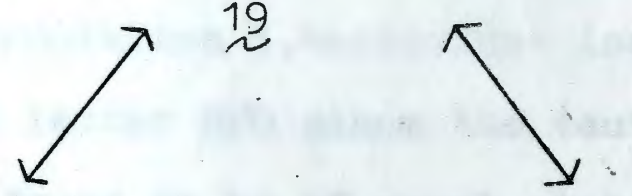

$\stackrel{7 b}{\sim}$

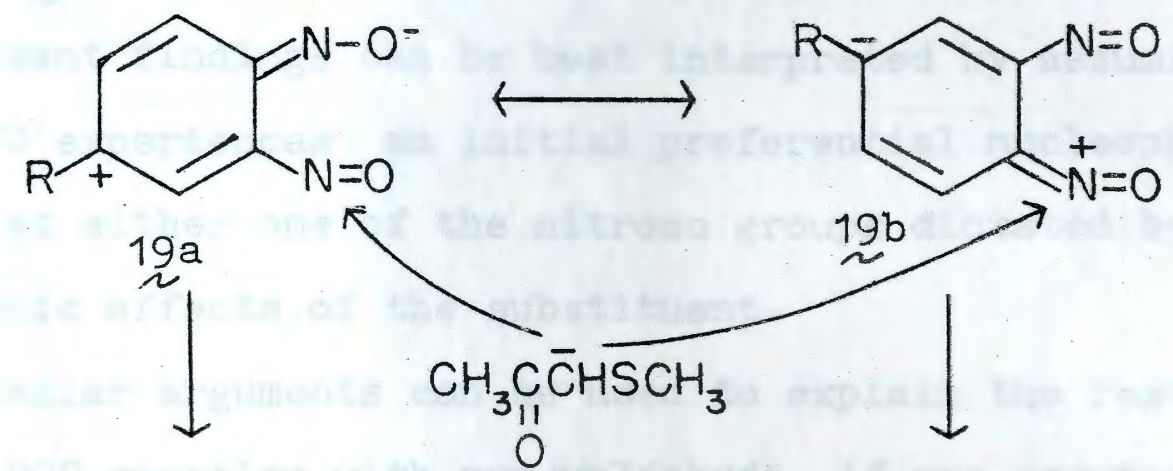

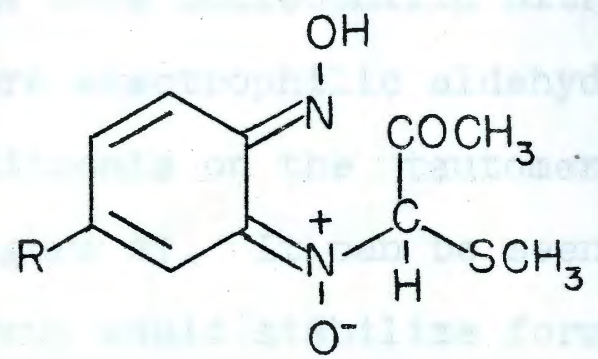

$\downarrow$<smiles>[R]c1ccc2c(c1)[n+]([O-])c(C)c(C)[n+]2[O-]</smiles>

42

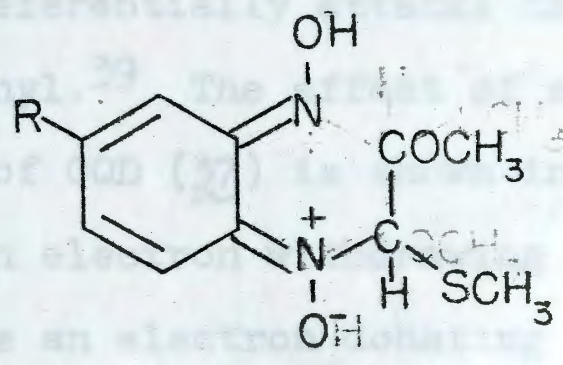

$\downarrow$

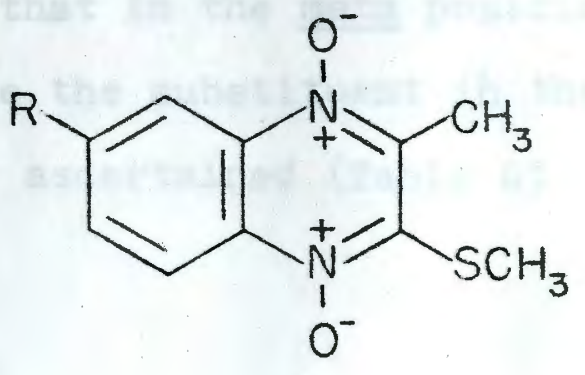

43 
An earlier proposal 30 suggested initial attack at $\mathrm{N}-3$ in the most stable form of $\mathrm{BFO}$, which is 7 for 5(6)-methoxy $\mathrm{BFO}$, to rationalize the formation of only the 7-isomers. Although such a mechanism explains the results obtained from the reaction of 5(6)-methoxy $\mathrm{BFO}$, it does not accomodate the data on the 5(6)-methyl compound. A 50:50 mixture of 6- and 7-methylquinoxaline 1,4-dioxide isomers would be expected from the latter $\mathrm{BFO}$ since the tautomeric forms $\left(7 \mathrm{a}\right.$ and $\mathrm{h}^{\mathrm{b}}$ ) were found to be of equal stability. 29 Thus, the present findings can be best interpreted by assuming that BFO experiences an initial preferential nucleophilic attack at either one of the nitroso groups dictated by the electronic effects of the substituent.

Similar arguments can be used to explain the results of the OQD reaction with pyruvaldehyde, if one assumes that the more nucleophilic nitrogen preferentially attacks the more electrophilic aldehyde carbonyl. 39 The effect of substituents on the tautomer forms of $O Q D$ (37) is shown in Figure 11. It can be seen that an electron withdrawing group would stabilize form A while an electron donating group would favor form B. In this latter form the para nitrogen is more nucleophilic than that in the meta position, and the product formed should have the substituent in the 6-position, as was experimentally ascertained (Table 4). 
Figure 11. Substituent Effects on OQD Resonance Structures

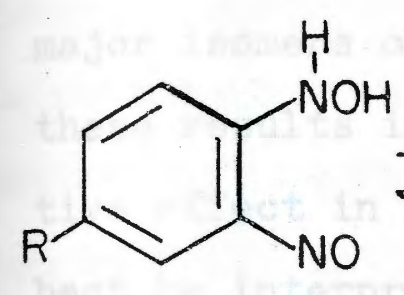

$\stackrel{\longrightarrow}{\longrightarrow}$
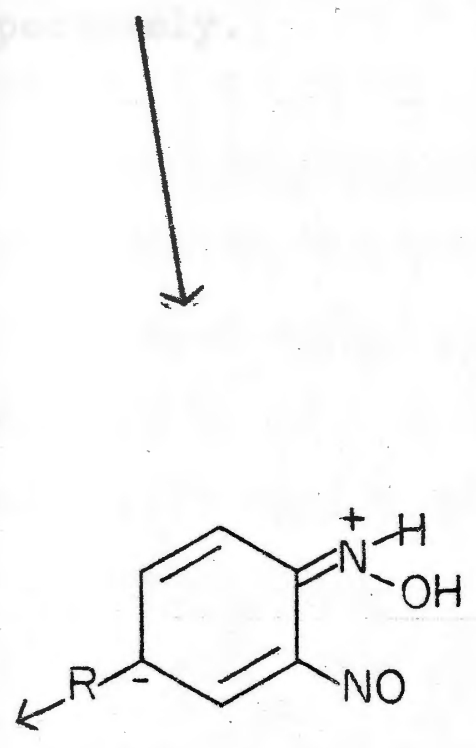

A

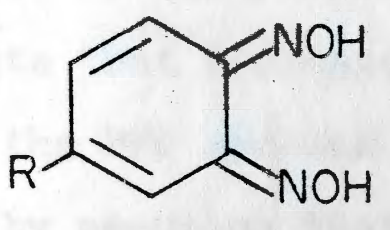

3.7

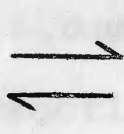

$R^{\prime}$<smiles>[R]c1ccc([N+](=O)[O-])c([N]O)c1</smiles>

$\stackrel{1}{H}$

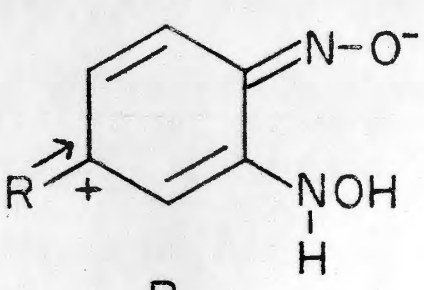

B

$A$ is more stable than $B$ when $R=$ electron withdrawing

$B$ is more stable than $A$ when $R=$ electron donating 


\section{CONCLUSION}

The results of this work support earlier contentions of Muffarij et al32 about the formation of 6- and 7-substituted quinoxaline 1,4-dioxide isomers, and are in partial agreement with Durckheimer, 33 and Mason and Tennant 30 in that their quinoxaline 1,4-dioxides obtained correspond to the major isomers obtained in the present work. In addition, these results indicate that 5(6)-substituents have a directive effect in both the $B F O$ and $O Q D$ reactions, which can best be interpreted by assuming that these species are reacting in their dinitroso and nitrosohydroxylamino forms, respectively. 


\section{EXPERIMENTAL}

Melting points were taken on a Thomas-Hoover capillary melting point apparatus and are uncorrected. Uv absorption spectra were obtained from a Bausch and Lomb Spectranic 505 spectrophotometer with methanol as the solvent. Ir absorption spectra were a determined on a Beckman IR-8 spectrophotometer, and all ir samples were prepared as solid dispersions in potassium bromide. Nmr spectra were recorded on either a Varian A-60 or Jeelco C-60-HL spectrometer. All nmr data can be found in Tables 1-3. Mass spectra were obtained on a Perkin-Elmer RMV-6E or CEC-104 spectrometer. Microanalyses were performed by Micro-Analysis, Inc., Marshallton, Delaware.

3,6(7)-Dimethyl-2-(methylthio)-quinoxaline 1,4 dioxide (35b). 5(6)-Methylbenzofurazan-1-oxide (4.00 g, 26.7 mmol) was dissolved in methanol $(100 \mathrm{ml})$, and (methylthio)-2-propanone $\mathrm{e}^{7}(2.40 \mathrm{~g}, 23.1 \mathrm{mmol})$ was added. Ammonia gas was then bubbled into this mixture for five minutes. The reaction mixture was allowed to stand overnight, and the product crystallized out. The crystals were filtered off and washed with methanol, and dried $(1.10 \mathrm{~g})$. The reaction mixture was then evaporated to dryness and the residue ( $5 \mathrm{~g})$ was column chromatographed on silica gel (150 g). Elution with chloroform $(700 \mathrm{ml})$ gave additional product $(1.30 \mathrm{~g})$; overall yield, 45\%. Recrystallization from methanol gave the analytical sample, m.p. 175-177 ; uv, nm, $240(13,500), 261(10,000)$, $293(8,840), 374$ (broad, 7,060); ir, $\mathrm{cm}^{-1}, 1333,1300$, and 
1030.

Anal: Calcd for $\mathrm{C}_{11} \mathrm{H}_{12} \mathrm{~N}_{2} \mathrm{O}_{2} \mathrm{~S}: \mathrm{C}, 55.92 ; \mathrm{H}, 5.11 ; \mathrm{N}$, 11.85. Found: C, 56.04; H, 4.92; N, 11.71.

3, (6)7-Dimethyl-1-hydroxy-2-iminoquinoxaline 4-oxide $(41 \mathrm{~b})$. Further elution of the column (see previous preparation) with $15 \%$ methanol in chloroform (600 $\mathrm{ml}$ ) furnished $0.216 \mathrm{~g}, \mathrm{~m} \cdot \mathrm{p} \cdot 239-240^{\circ}$ (dec). The compound was synthesized directly by adding ammonia gas to a solution of $35 \mathrm{~b}(1.05 \mathrm{~g}$, $4.45 \mathrm{mmol}$ ) dissolved in methanol (100 $\mathrm{ml})$. The reaction mixture was allowed to stand at room temperature for several days (or until TLC (silica gel, 5\% methanol in chloroform) showed no starting material). Partial evaporation of the solvent resulted in crystallization of the product, $0.467 \mathrm{~g}$ (51\%). Recrystallization from water gave the analytical sample, m.p. 239-2410 (dec); uv, nm, $236(12,700), 266(29,200)$, $343(7,220), 395(7,550)$; ir $\mathrm{cm}^{-1}, 3280,3130$ (broad), 1640, and 1345 .

Anal. Calcd for $\mathrm{C}_{1} \mathrm{H}_{11} \mathrm{~N}_{3} \mathrm{O}_{2}: \mathrm{C}, 58.74 ; \mathrm{H}, 5.37 ; \mathrm{N}$, 20.37. Found: C, 58.67; H, 5.38; N, 20.48.

6(7)-Methoxy-3-methyl-2-(methylthio)-quinoxaline' 1,4-dioxide (35a). 5(6)-Methoxybenzofurazan-1-oxide (1.3 g, 7.9 mmol) was dissolved in methanol. (20 ml) by warming. To this solution was added (methylthiot-2-propanone $(1.0 \mathrm{~g}, 9.6 \mathrm{mmol}$ ), and then ammonia gas was bubbled into this solution for five minutes. The reaction mixture was allowed to stand at room temperature overnight. The product was filtered off and 
washed with methanol (1.05 g), m.p. 145-1500. The mother liquor was evaporated to dryness and the residue $(1 \mathrm{~g})$ was chromatographed on silica gel $(30 \mathrm{~g})$. Elution with $1 \%$ methanol in chloroform $(175 \mathrm{ml}$ ) gave $0.30 \mathrm{~g}$ more of the product which was combined with the first crop $(1.35 \mathrm{~g}, 68 \%)$, and recrystallized from methanol, m.p. 1550; uv, nm, 248, $(13,450), 298(9,670), 372$ (broad, 5040); ir, $\mathrm{cm}^{-1}, 1330$, $1302,1205,1033$, and 828.

Anal. Calcd for $\mathrm{C}_{11} \mathrm{H}_{12} \mathrm{~N}_{2} \mathrm{O}_{3} \mathrm{~S}: \mathrm{C}, 52.38 ; \mathrm{H}, 4.76 ; \mathrm{N}$, 11.11. Found: C, 52.02; H, 4.83; N, 11.11.

1-Hydroxy-2-imino-6(7)-methoxy-3-methylquinoxaline 4oxide (41a). Further elution of the column (see previous preparation) with $15 \%$ methanol in chloroform (125 ml) furnished $0.046 \mathrm{~g}(4 \%)$ of product, m.p. $253-255^{\circ}$ (dec). The compound was prepared directly by bubbling ammonia into a warm solution of $35 \mathrm{a}(0.093 \mathrm{~g}, 0.37 \mathrm{mmol}$ ) in methanol (10 $\mathrm{ml})$. The stoppered mixture was allowed to stand at room temperature in darkness. After one week, the mixture was filtered and the residue was washed with methanol, $(0.055 \mathrm{~g}$, 67\%). Recrystallization from water gave the analytical sample, m.p. 253-2550 (dec); uv, nm, 268 (14,600); ir, $\mathrm{cm}^{-1}$, $3390-3326,1626,1515,1335,1264$, and 1236; mass spectrum, $\mathrm{m} / \mathrm{e}, 221,188(100 \%)$.

Anal. Calcd for $\mathrm{C}_{10} \mathrm{H}_{11} \mathrm{~N}_{3} \mathrm{O}_{3}$ : C, 54.29; H, 4.97; N, 19.00. Found: C, 54.51; H, 5.23; N, 18.79.

3,6-Dimethyl and 3,7-dimethy 1-1-hydroxyquínoxaline-2- 
one 4-oxide (36b). Method A - To a suspension of 4-methylo-quinone dioxime $(1.08 \mathrm{~g}, 7.50 \mathrm{mmol})$ in water $(35 \mathrm{ml})$ was added $40 \%$ aqueous pyruvaldehyde $(3.0 \mathrm{ml}, 7.5 \mathrm{mmol})$. The yellow suspension immediately changed to a reddish-brown color, and upon being warmed on a steam bath, the mixture returned to a yellow color. When cool, the precipitate was collected $(1.4 \mathrm{~g}), \mathrm{m} \cdot \mathrm{p} \cdot 214-220^{\circ}$ (dec). Recrystallization from trifluoroacetic acid/methanol gave the analytical sample $(1.28 \mathrm{~g}$, 83\%), m.p. 228-2320 (dec); ir, cm-1, 1667, 1605, 1323, 1232, 1149, and 958; uv, $\mathrm{nm}, 235(4,740), 260(5,820)$, and 316 $(1,210)$. Nmr analysis showed the presence of both the 3,6dimethyl and 3,7-dimethyl isomers.

Anal. Calcd for $\mathrm{C}_{10} \mathrm{H}_{10} \mathrm{~N}_{2} \mathrm{O}_{3}: \mathrm{C}, 58.26 ; \mathrm{H}, 4.89 ; \mathrm{N}$, 13.58. Found: C, 58.25; H, 5.04; N, 13.32 .

Method B - The product was also prepared by adding 3\% aqueous potassium hydroxide $(60 \mathrm{ml})$ to $34 \mathrm{~b}(1.08 \mathrm{~g}, 4.58$ mmol). The mixture was heated on a steam bath until a solution formed. The solution was cooled and neutralized with concentrated $\mathrm{HCl}$. The precipitate that formed was collected by filtration, $(0.65 \mathrm{~g}, 69 \%), \mathrm{m} \cdot \mathrm{p} .228-230^{\circ}$. Nmr analysis showed the presence of both the 3,6-dimethyl and 3,7-dimethyl isomers.

Anal. Calcd for $\mathrm{C}_{10} \mathrm{H}_{10} \mathrm{~N}_{2} \mathrm{O}_{3}: \mathrm{C}, 58.26 ; \mathrm{H}, 4.89 ; \mathrm{N}$, 13.58. Found: C, $57.95 ; \mathrm{H}, 5.07 ; \mathrm{N}, 13.35$.

1-Hydroxy-6-methoxy-3-methylquinoxaline-2-one-4-oxide and 1-hydroxy-7-methoxy-3-methylquinoxaline-2-one-4-oxide 
(36a). Method A - 4-Methoxy-o-benzoquinone dioxime $(0.85 \mathrm{~g}$, $5.0 \mathrm{mmol}$ ) was suspended in water ( $25 \mathrm{ml})$, and $40 \%$ aqueous pyruvaldehyde $(2.0 \mathrm{ml}, 5.0 \mathrm{mmol})$ was added. The reaction mixture became dark brown, and upon being warmed on a steam bath it turned yellow. When cool, the precipitate that formed was filtered off $(0.88 \mathrm{~g}, 80 \%)$. Recrystallization from trifluoracetic acid/nethanol gave the analytical sample, m.p. 252-2550 (dec); ir, $\mathrm{cm}^{-1}, 3125-3077,1613,1515$, 1379, 1242, 1030, and 820; uv, nm, 234 (9160), 254 (7100). Nrnr analysis showed the presence of both the 6-methoxy and 7-methoxy isomers.

Anal. Calcd for $\mathrm{C}_{10} \mathrm{H}_{10} \mathrm{~N}_{2} \mathrm{O}_{4}: \mathrm{C}, 54.06 ; \mathrm{H}, 4.54 ; \mathrm{N}$, 12.61. Found: C, 53.78; H, 4.48; N, 12.74 .

Method B - A solution of $34 \mathrm{a}(2.1 \mathrm{~g}, 8.4 \mathrm{mmol})$ in $2 \mathrm{M}$ potassium hydroxide $(60 \mathrm{ml})$ was obtained by heating the suspension on a steam bath. The reaction mixture was cooled and filtered. To the filtrate was added $6 \mathrm{M} \mathrm{HCl}$ until precipitation was complete. The light tan precipitate was collected and washed with water $(1.7 \mathrm{~g}, 92 \%), \mathrm{m} \cdot \mathrm{p} \cdot 210-212^{\circ}$ (dec); ir , cm-1, 1672, 1616, 1247, 1222, 1152, and 957; uv, $n m, 237(11,400), 264(11,600)$, and $347(4,840)$. Nmr data showed the presence of both the 6-methoxy and 7-methoxy isomers.

Anal. Calcd for $\mathrm{C}_{10} \mathrm{H}_{10} \mathrm{~N}_{2} \mathrm{O}_{4}: \cdot \mathrm{C}, 54.06 ; \mathrm{H}, 4.54 ; \mathrm{N}$, 12.61. Found: C, 53.99; H, 4.55; N, 12.48 .

3,6-Dimethyl-1-methoxyquinoxaline-L-one-4-oxide (39b,1). 
Compound 36b ( $0.897 \mathrm{~g}, 4.36 \mathrm{mmol})$ obtained from method A was added to previously purified 40 dimethyl sulfate $(0.60 \mathrm{ml}$, $6.2 \mathrm{mmol})$ dissolved in dry acetone $(250 \mathrm{ml})$. After the addition of potassium carbonate $(0.75 \mathrm{~g})$ the reaction mixture was refluxed overnight. Then the solvent was removed, and the residue was dissolved in chloroform. To this solution was added an aqueous solution of potassium carbonate $(1.0 \mathrm{M})$, and this mixture was stirred overnight. The chloroform portion was separated and dried over anhydrous magnesium sulfate, and then treated with activated carbon. Evaporation of the chloroform gave a residue $(0.736 \mathrm{~g})$, m.p. $146-148^{\circ}$; Nmr analysis showed the presence of both the 3,6-dimethyl and 3,7-dimethyl isomers (Figure 7).

Anal. Calcd for $\mathrm{C}_{11} \mathrm{H}_{12} \mathrm{~N}_{2} \mathrm{O}_{3}: \mathrm{C}, 60.21 ; \mathrm{H}, 5.46 ; \mathrm{N}$, 12.65. Found: C, 60.19; H, 5.56; N, 12.84 .

The residue was recrystallized three times from chloroform/ ether to give the pure 3,6-dimethyl isomer $(0.03 \mathrm{~g})$, m.p. 171-1730; ir $\mathrm{cm}^{-1}, 1658 ; 1527 ; 1333,1297,1221$, and 964; uv. $\mathrm{nm}, 230(13,700), 257(4,720), 299(3,570)$, and 355 $(2,430)$.

Anal. Calcd for $\mathrm{C}_{11} \mathrm{H}_{12} \mathrm{~N}_{2} \mathrm{O}_{3}: \mathrm{C}, 60.21 ; \mathrm{H}, 5.46 ; \mathrm{N}$, 12.65. Found: C, 60.09; H, 5.45; N, 12.93 .

3,7-Dimethyl-1-methoxyquinoxaline-2-one-4-oxide (39p,2). Compound $36 \mathrm{~b}(0.65 \mathrm{~g}, 3.2 \mathrm{mmol})$ obtained from Method B was added to dimethyl sulfate $(0.38 \mathrm{ml}, 4.0 \mathrm{mmol})$ in dry acetone $(175 \mathrm{ml})$. After the addition of potassium carbonate $(0.4 \mathrm{~g})$ 
the reaction mixture was refluxed overnight. Evaporation of the solvent left a residue which was redissolved in chloroform, and stirred with potassium carbonate solution (1.0 M) overnight. The chloroform layer was separated, dried over anhydrous magnesium sulfate and evaporated to dryness to give the crude product $(0.58 \mathrm{~g}, 80 \%), \mathrm{m} . \mathrm{p} \cdot 149-154^{\circ}$. Nmr analysis showed the presence of both 3,7-dimethyl and 3,6-dimethyl isomers.

Anal. Calcd for $\mathrm{C}_{11} \mathrm{H}_{12} \mathrm{~N}_{2} \mathrm{O}_{3}: \mathrm{C}, 60.21 ; \mathrm{H}, 5.46 ; \mathrm{N}$, 12.65. Found: C, 60.12; H, 5.37; N, 12.76. The residue was recrystallized three times from chloroform/ ether to furnish the pure 3,7-dimethyl isomer (.4 g, 34\%), m.p. 186-1880; ir, cm-1, 1653, 1600, 1319, 1242, 1202, 1044, 966,810 , and 711; uv, nm, $230(30,000) ; 256(\mathrm{sh})(17,400)$, and $300(17,200)$.

Anal. Calcd for $\mathrm{C}_{11} \mathrm{H}_{12} \mathrm{~N}_{2} \mathrm{O}_{3}: \mathrm{C}, 60.21 ; \mathrm{H}, 5.46 ; \mathrm{N}$, 12.65. Found: C, 60.09; H, 5.88; N, 12.47 .

1,6-Dimethoxy-3-methylquinoxaline-2-one-4-oxide $(38 a, 1)$. Compound $36 \mathrm{a}(1.10 \mathrm{~g}, 4.95 \mathrm{mmol})$ obtained from Method A was added to a solution of diazomethane in ether. After one hour of stirring at room temperature complete solution was achieved. Excess diazomethane was decomposed with acetic acid followed by neutralization with sodium bicarbonate solution. After drying over magnesium sulfate, the solution was filtered and allowed to evaporate giving the crude product $(1.0 \mathrm{~g}$, $94 \%), m \cdot p \cdot 160^{\circ}$ (dec); nmr data indicated the presence of 
both the 1,6-dimethoxy and 1,7-dimethoxy isomers (Figure 8). Anal. Calcd for $\mathrm{C}_{11} \mathrm{H}_{12} \mathrm{~N}_{2} \mathrm{O}_{4}$ : C, 55.92; $\mathrm{H}, 5.12 ; \mathrm{N}$, 11.86. Found: C, 55.87; H, 5.04; N, 11.58.

Recrystallization with chloroform/ether three times gave the pure isomer (.104 g, 9.8\%), m.p. 183-1850; ir, cm-1, 1645, $1520,1332,1290,1263,1235$, and 1030, uv, nm, $235(21,000)$, $264(5,580)$, and $352(7,720)$.

Anal. Calcd for $\mathrm{C}_{11} \mathrm{H}_{12} \mathrm{~N}_{2} \mathrm{O}_{4}$ : C, 55.92; H, 5.12; $\mathrm{N}$, 11.86. Found: C, 56.07; H, 5.32; N, 11.63.

1,7-Dimethoxy-3-methylquinoxaline-2-one-4-oxide $(38 a, 2)$. Compound $36 \mathrm{a}(1.10 \mathrm{~g}, 4.95 \mathrm{mmol})$ obtained from method B was added to an ice-cold solution of diazomethane in ether. The mixture was kept cool and it was stirred for one hour. It was then filtered, and the filtrate was washed with sodium carbonate, and then dried over magnesium sulfate. Both the filtrate and precipitate were combined and the solvent was evaporated to yield the crude product $(0.95 \mathrm{~g}, 82 \%)$, m.p. $180-185^{\circ}$ (dec); nmr analysis showed the presence of both the 1,6-dimethyl and 1,7-dimethyl isomers.

Anal. Calcd for $\mathrm{C}_{11} \mathrm{H}_{12} \mathrm{~N}_{2} \mathrm{O}_{4}: \mathrm{C}, 55.92 ; \mathrm{H}, 5.12 ; \mathrm{N}$, 11.86. Found: C, 56.02; H, 5.19; N, 11.56.

Three recrystallizations from chloroform/ether furnished the pure 1,7-dimethyl isomer $(0.065 \mathrm{~g}, 5.6 \%)$ m.p. 191-1930; uv, $\mathrm{nm}, 236(28,900), 264(5,580)$, and $352(7,720)$; ir, $\mathrm{cm}^{-1}$; $1653,1608,1333,1238,1190,1099,971$, and 853.

Anal. Calcd for $\mathrm{C}_{11} \mathrm{H}_{12} \mathrm{~N}_{2} \mathrm{O}_{4}: C, 55.92 ; \mathrm{H}, 5.12 ; \mathrm{N}$, 11.86. Found: C, 56.16; H, 5.11; N, 11.51. 


\section{REEERENCES}

1. G.R. Clemo and H. McIlwain, J. Chem. Soc., 479 (1938).

2. H. McIlwain, Nature, 148, 628 (1941).

3. G.R. Clemo and A.F. Daglish, J. Chem. Soc., 1481 (1950).

4. E.C. White and J.H. Hill, J. Bacteriol., 45, 433 (1943).

5. J.D. Dutcher, J. Biol. Chem., 171, 321 (1947).

6. G. Dunn, J.J. Gallagher, G.T. Newbold, and F.S. Spring, J. Chem. Soc. (Supp1.), 126 (1949).

7. E.H. Peterson, D.C. Gillespie, and F.D. Cook, Canad. J. Microbiol., 12, 221 (1966).

8. M. Weigle and W. Leimgruber, Tet. Lett., 715 (1967).

9. G. Maestrone, R. Darker, F. Hemrick, and M. Mitrovic, J. Am. Med. Vet. Assn., 33, 185 (1972).

10. E. Stapley, U.S. Patent 3598819 (1971).

11. W. Hurst, J.K. Landquist, J.M. Peters, N. Simon, J.A. Silk, and G.J. Stacey, Brit. J. Pharmacol., 8, 297 (1953).

12. A.R. English and C. Dunegan, Proc. Soc. Exptl. Biol. and Med., 133, 398 (1970).

13. H. McIlwain, J. Chem. Soc., 322 (1943).

14. J.R. Valenta, J.R.E. Hoover, and J.F. Pagano, Antimicrobial Agents and Chemother., 453 (1966).

15. M.J. Haddadin and C.H. Issidorides, Tet. Lett., 3253 (1965).

16. C.H. Issordorides and M.J. Haddadin, J. Org. Chem., 31, $4067(1.966)$.

17. E.T. Kornegay, J.W. Davis, and H.R. Thomas, J. Anim. Sci., 27. 1134 (1968).

18. J.W. Davis, K.G. Libke, and E.T. Kornegay, I. Am. Med. Vet. Assn., 153, 1181 (1968).

19. G.W. Thrasher, J. Anim. Sci., 28, 208 (1969). 
20. Imperial Chemical Industries, Ltd., French Patent 2021953 (1970); Chem. Abstr., 75, $34267 f$ (1971). Marwan El-Haj, German Patent 2111710 (1971); Chem. Abstr., 76, 3900y (1972). Ernst Scheizer and Christian Egli, South African Patent 7101072 (1971); Chem. Abstr., 76, 153780y (1972).

21. Farbenfabriken Bayer, German Patent 1935294 (1971); Chem. Abstr., 74, 88057k (1971).

22. E. Absuhanab, J. Org. Chem., 35, 4279 (1970).

23. J.W. McFarland, ibid., 36, 1842 (1971).

24. A.R. Katritzky, S. Oksne, and R.K. Harris, Chem. and Ind., 990 (1961).

25. G. Englert, Z. Analyt. Chem., 181, 447 (1961).

26. F.B. Mallory and C.S. Wood, Proc. Nat. Acad. Sci., 47, 697 (1961).

27. R.K. Harris, A.R. Katritzky, S. Oksne, A.S. Baily, and W.G. Paterson, J. Chem. Soc., 197 (1963).

28. P. Kiehl, H.A. Christ, and F.B. Mallory, Helv. Chem. Acta, 45, 504 (1962).

29. A.J. Boulton, A.R. Katritzky, M.J. Sewell, and B. Wallis, J. Chem. Soc., 914 (1967).

30. J.C. Mason and G. Tennant, Chem. Comm., 586 (1971).

31. M.J. Haddadin, G. Agopian, and C.H. Issidorides, J. Org. Chem., 36, 514 (1971).

32. M.A. Mufarrij, M.J. Haddadin, C.H. Issidorides, J.W. McFarland, and J.D. Johnston, J. Chem. Soc. Perkin Transactions I., 965 (1972).

33. W. Durckheimer, Leibigs Ann. Chem., 756, 145-54 (1972).

34. "Organic Syntheses," Coll. Vol. IV, John Wiley and Sons, Inc., New York (1963), p. 74.

35. a) A.G. Green and F.M. Rowe, J. Chem. Soc., 101 (1912).

b) A.G. Green and F.M. Rowe, ibid., 103.(1913).

36. R.J. Gaughran, J.P. Picard, and J.V.R. Kaufman, J. Am. Chem. Soc., 76, 2233 (1954). 
37. C.K. Bradsher, F.C. Brown, and R.S. Grantham, ibid., 76, 114 (1954).

38. G. Tappi and P.V. Forni, Ann. Chem. appl. 39, 338 (1949).

39. J. March, "Advanced Organic Chemistry: Reactions, Mechanisms, and Structure," McGraw-Hill Co., New York (1968), p. 653.

40. A.I. Vogel, "Practical Organic Chemistry," Spottiswoode, Ballantyne and Co., Ltd., London (1966), p. 804. 